\section{ECOHFTOR}

Make Your Publications Visible.
A Service of

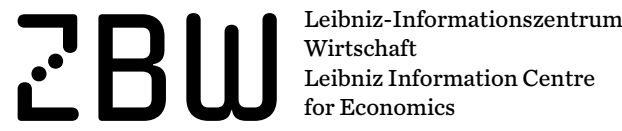

Magda, Iga; Gromadzki, Jan; Moriconi, Simone

\title{
Working Paper \\ Firms and Wage Inequality in Central and Eastern Europe
}

IZA Discussion Papers, No. 12214

Provided in Cooperation with:

IZA - Institute of Labor Economics

Suggested Citation: Magda, Iga; Gromadzki, Jan; Moriconi, Simone (2019) : Firms and Wage Inequality in Central and Eastern Europe, IZA Discussion Papers, No. 12214, Institute of Labor Economics (IZA), Bonn

This Version is available at:

http://hdl.handle.net/10419/196712

\section{Standard-Nutzungsbedingungen:}

Die Dokumente auf EconStor dürfen zu eigenen wissenschaftlichen Zwecken und zum Privatgebrauch gespeichert und kopiert werden.

Sie dürfen die Dokumente nicht für öffentliche oder kommerzielle Zwecke vervielfältigen, öffentlich ausstellen, öffentlich zugänglich machen, vertreiben oder anderweitig nutzen.

Sofern die Verfasser die Dokumente unter Open-Content-Lizenzen (insbesondere CC-Lizenzen) zur Verfügung gestellt haben sollten, gelten abweichend von diesen Nutzungsbedingungen die in der dort genannten Lizenz gewährten Nutzungsrechte.
Terms of use:

Documents in EconStor may be saved and copied for your personal and scholarly purposes.

You are not to copy documents for public or commercial purposes, to exhibit the documents publicly, to make them publicly available on the internet, or to distribute or otherwise use the documents in public.

If the documents have been made available under an Open Content Licence (especially Creative Commons Licences), you may exercise further usage rights as specified in the indicated licence. 


\section{Z A Institute of Labor Economics}

Initiated by Deutsche Post Foundation

\section{DISCUSSION PAPER SERIES}

IZA DP No. 12214

Firms and Wage Inequality in Central and Eastern Europe

Iga Magda

Jan Gromadzki

Simone Moriconi 


\section{Z A Institute of Labor Economics}

Initiated by Deutsche Post Foundation

\section{DISCUSSION PAPER SERIES}

IZA DP No. 12214

\section{Firms and Wage Inequality in Central and Eastern Europe}

\section{Iga Magda}

Warsaw School of Economics, IBS and IZA

\section{Jan Gromadzki}

Warsaw School of Economics and IBS

\section{Simone Moriconi}

IÉSEG School of Management and LEM-CNRS 9221

Any opinions expressed in this paper are those of the author(s) and not those of IZA. Research published in this series may include views on policy, but IZA takes no institutional policy positions. The IZA research network is committed to the IZA Guiding Principles of Research Integrity.

The IZA Institute of Labor Economics is an independent economic research institute that conducts research in labor economics and offers evidence-based policy advice on labor market issues. Supported by the Deutsche Post Foundation, IZA runs the world's largest network of economists, whose research aims to provide answers to the global labor market challenges of our time. Our key objective is to build bridges between academic research, policymakers and society.

IZA Discussion Papers often represent preliminary work and are circulated to encourage discussion. Citation of such a paper should account for its provisional character. A revised version may be available directly from the author. 


\section{ABSTRACT}

\section{Firms and Wage Inequality in Central and Eastern Europe*}

Recent studies show that firms are playing an increasingly important role in shaping wage inequality in advanced economies. We contribute to this literature by analysing wage inequality patterns and their firm dimension in Central and Eastern European countries. We use large, linked employer-employee datasets with data from the 2002-2014 period. We find that unlike in many other advanced economies, wage inequality levels have decreased in CEE countries, and particularly in those countries that previously had the highest wage inequality levels. The relative size of the between-firm component varied substantially across countries, and was largest in countries with the highest wage inequality levels. We further estimate the recentered influence function (RIF) regression and the Blinder-Oaxaca decomposition in order to investigate the micro-level determinants of wage inequality. Our findings indicate that the changes in wage inequality levels were mainly attributable to returns to workplace characteristics.

JEL Classification:

D22, J31, J40

Keywords:

wages, wage inequality, RIF regression, linked employer-

employee data

\section{Corresponding author:}

Iga Magda

Institute for Structural Research (IBS)

Wiśniowa 40B/8

02-520 Warsaw

Poland

E-mail: iga.magda@ibs.org.pl

\footnotetext{
* This paper has benefited from the financial support provided by the National Science Center, Poland (DEC2013/10/E/HS4/00445) and by the World Bank Group (FY2016 DGF Network for Jobs and Development-DGF File: 502916-05). We would like to thank Peter Orazem, the participants of the 2018 EALE, 2018 IZA World Labour conference and the 2018 HSE/IZA workshop for their comments and remarks. We also gratefully acknowledge use of the Python/Stata template provided by von Gaudecker (2014). This paper uses Eurostat data. Eurostat has no responsibility for the results and the conclusions, which are those of the authors.
} 


\section{Introduction}

The issue of increasing income inequality is being publicly debated in most OECD countries. Many of the questions raised in these discussions centre around the extent to which changes in wage inequality levels are driving income differentials. Much of the existing literature on this topic has focused on firm-level determinants, and has recognised the important role of inter-industry and firm wage differentials (Abowd, Kramarz, \& Margolis, 1999; Du Caju, Kátay, Lamo, Nicolitsas, \& Poelhekke, 2010; Krueger \& Summers, 1988; Martins, 2004). We know far less about how between-firm wage inequality levels change over time, and whether firm-level factors have contributed to the increases in wage inequality levels observed in many OECD countries. This paper contributes to this debate by investigating the workplace features that are likely to drive wage inequality and its changes. While there is extensive research on determinants of wage inequality in the US, Germany, and many other advanced countries, this paper focuses on Central and Eastern European (CEE) countries. CEE countries are interesting not only because comparative evidence on changes in their wage structure is scant, but because this geographical region has distinct cross-country patterns in wage inequality trends. In recent decades, wage inequality levels have increased in many advanced countries, but have stabilised or declined in CEE countries. There is evidence that the recent rise in wage inequality in the US was driven by increasing between-firm wage inequality. We answer the question on whether changes in between-firm inequality could also stand behind the decreases in wage inequality in the CEE.

This paper has three main objectives. First, we aim to present a clear picture of changes in the wage dispersion patterns in CEE countries between 2002 and 2014 using harmonised, comparative data from a large, linked employer-employee dataset of the European Structure of Earnings Survey (ESES). Second, we intend to analyse the role of companies in determining wage inequality, and to examine how much of this inequality is due to wage differentials arising between firms, and how much is due to within-firm wage inequality. Third, we will investigate the potential micro-level factors associated with higher or lower levels of wage inequality, and particularly the drivers of the observed decrease in wage inequality during the 2002-2014 period. We seek to gain additional insight into determinants of wage inequality by applying 
recentered influence function (RIF) regressions following Firpo, Fortin, and Lemieux (2018).

Our results suggest that during the 2002-2014 period, wage inequality levels decreased in most CEE countries (especially in the Baltic states and Romania, where the initial wage inequality levels were the highest in the region), while the Czech Republic (where the wage inequality level remains the lowest in the region) was the only CEE country that experienced a (slight) increase in wage inequality. We further show that the differences in the variance of wages across the CEE countries were driven by differences in the between-firm component of wage inequality (and to a lesser extent by wage inequality within firms). We gain further insight into the determinants of wage inequality by applying recentered influence function (RIF) regressions following Firpo et al. (2018). We show that workplace characteristics were more important than personal, supply-side covariates in explaining wage inequalities. In particular, we find that among these workplace characteristics, the educational levels and ages of an employee's co-workers were as crucial as her/his occupational or sectoral affiliation. By applying standard decomposition techniques to each cross-section, we find that reductions in wage inequality in the region between 2006 and 2014 were largely attributable to changes in the individualand firm-level "coefficients", rather than to changes in "endowments". Finally, changes in the structure of the workforce (primarily the rising share of tertiary-educated workers) would have led to increases in wage inequality if the wage returns to personal, job, and firm characteristics had remained constant.

\section{Literature review}

Our paper is related to two main strands of literature. The first strand is comprised of studies on changes in wage inequality and their determinants. Some of the most important works on this topic include Autor, Katz, and Kearney (2006); Autor, Katz, and Kearney (2008) for the US; Fortin, Green, Lemieux, Milligan, and Riddell (2012) for Canada; Dustmann, Ludsteck, and Schönberg (2009) for Germany; and Machin (2016) for the UK. This literature has looked at the macro-level drivers of wage inequality, and has examined how trade and labour market frictions, technological change, and migration have contributed to wage inequality (Acemoglu \& Autor, 2011; Akerman, Helpman, Itskhoki, Muendler, \& Redding, 2013; Autor, 
Manning, \& Smith, 2016; Ge \& Yang, 2014; Goldschmidt \& Schmieder, 2017; Helpman, Itskhoki, Muendler, \& Redding, 2017; Krishna, Poole, \& Senses, 2012). Some studies (Autor et al., 2008; Lemieux, 2006) have taken a micro perspective, and have shown that the rise in wage inequality has been highly heterogeneous across worker characteristics, including education, age, and type of occupation. A striking feature of the steady rise in wage inequality that took place in the US from the 1970s onwards is that earnings increased more at higher percentiles of the earnings distribution, even for the same level of skill. The literature on this trend has grown considerably in recent decades, and has focused mainly on developed economies (the US and Western European countries) and some emerging economies (e.g., Brazil, China, see Alvarez, Benguria, Engbom, and Moser (2018); Appleton, Song, and Xia (2014); Messina and Silva (2017)). Only a few studies have dealt explicitly with recent developments in wage inequality in the CEE countries, which experienced a strong increase in wage dispersion during the transition to a market economy (Aristei \& Perugini, 2014; Milanovic \& Ersado, 2012). This phase seems to have been followed by a period in which the wage distribution was slowly compressing (Tyrowicz \& Smyk, 2019); although the patterns varied across countries (Aristei \& Perugini, 2012). Pryor (2014) emphasised that even after the surge in wage inequality levels during the transition, the degree of wage dispersion remained lower (around 2000s) in the CEE countries than it was in most OECD countries. A more recent study by Mysíková and Večerník (2018) compared the developments in wage inequality in Poland and the Czech Republic with those in Austria just before and after the Great Recession (2007). For the two CEE countries, they found that income polarisation did not increase, and wage inequality remained low along the gender, skill, and occupational dimensions. Our paper contributes to this literature by showing that wage inequality decreased in nine CEE countries during the 2000-2014 period.

The second strand of literature we want to contribute to focuses on firm-level drivers of wage inequality. The overall level of wage inequality can be decomposed into a within-firm component (wage differentials that arise within firms) and a between-firm component (differences in the average wages of firms). Establishment effects matter, as employers are affected differently by the various factors that shape changes in the wage distribution, such as skill-biased technological change or changes in labour market institutions, whereas workers are sorted among employers. Card, Cardoso, Heining, and Kline (2018) developed a theoretical model of wage 
setting in which workers are assumed to have idiosyncratic tastes for different workplaces. An increase in firm productivity leads to an increase in individual wages because firms do not observe workers' preference shocks. Thus, an increase in the dispersion of productivity across firms will lead to an increase in levels of between-firm wage inequality. The propagation of productivity increases to wages depends directly on rent-sharing elasticity. For the UK, Bell, Bukowski, and Machin (2018) found that rent-sharing elasticity has decreased sharply since the 1980s, which has resulted in a reduction in the impact of increasing productivity differentials on wage inequality. Hence, it seems that increases in the dispersion of firm productivity can explain only a portion of the observed increases in levels of between-firm wage inequality.

The empirical studies on the contribution of the between-firm component were summarised by Card et al. (2018). Barth, Bryson, Davis, and Freeman (2016) has shown that the increased variance of average earnings across establishments can explain about half of the rise in US wage inequality during the 1970-2000 period. Handwerker and Spletzer (2016) showed that the growing contribution of establishment effects to the widening of the distribution of wages is only partially explained by changes in the distribution of occupations among workplaces. Song, Price, Guvenen, Bloom, and von Wachter (2019) used linked employer-employee data to analyse the contributions of firms to the rise in earnings inequality in the United States from 1978 to 2013. They showed that about two-thirds of the increase in the variance of $(\log )$ earnings occurred between firms. They pointed out that the heterogeneity of the composition of the workforce among firms played a major role in this development. In a similar vein, Antonczyk, Fitzenberger, and Sommerfeld (2010) found that workplace effects contributed substantially to the increase in wage inequality in Germany. Card, Heining, and Kline (2013) also looked at West Germany (between 1985 and 2009), and confirmed that increasing firmlevel heterogeneity explained a large share of the rise in wage inequality. By contrast, the role of the between-firm component was found to be relatively small in Sweden (Akerman et al., 2013).

Very few studies have touched upon the potential role of firms in shaping wage inequality in the CEE countries, though a recent World Bank report (Kelly, Liaplina, Tan, \& Winkler, 2017) has suggested that in Bulgaria, Estonia, and Latvia, differences in wages across firms explain more than half of wage inequality, while differences in educational attainment or oc- 
cupations across workers explain only a third or less of wage inequality.

We add three contributions to the previous literature. First, we provide new, recent evidence based on harmonised data on levels of wage inequality in the CEE countries, and on how these levels have changed since the early 2000s. Second, we investigate the contribution of the between-firm component to the levels of and the changes in overall wage inequality in nine CEE countries. Finally, we conduct a detailed analysis of the micro-level determinants of wage inequality, and of how wage inequality changed over time.

\section{Data}

We use repeated cross-sectional data from the European Structure of Earnings Survey (ESES) for the years 2002, 2006, 2010, and 2014. The ESES is a large matched employer-employee dataset provided by Eurostat. It includes information on workers' earnings, and on their individual-, job-, and firm-level characteristics. We use data for the following nine CEE countries: the Czech Republic, Estonia, Hungary, Lithuania, Latvia, Poland, Romania, Slovakia, and Bulgaria. We additionally draw on ESES data for the Netherlands, Norway, Sweden, and Portugal in order to compare some of our results with those of Western European countries.

While the ESES data are characterised by a high degree of cross-country comparability, we had to carry out a number of cleaning steps to guarantee that the national samples and our analyses were fully harmonised across countries. In particular, we dropped observations that referred to workers in the smallest firms (fewer than 10 workers), because comparable data were available for only some of the countries. We also dropped observations from the top and the bottom $0.1 \%$ of the hourly wage distribution to avoid outliers. In the 2002 wave of the survey, the inclusion of observations from the non-market services sector was optional. Because the 2002 data for Estonia, Latvia, Hungary, Norway, Portugal, and Sweden are incomplete, we were not able to obtain comparable datasets for all countries for that year. For this reason, we have chosen to analyse the 2002 data only for countries with datasets that included all sectors, and to provide some of the analyses for the 2006-2014 period only. The sizes of the final samples range from 26,000 observations in Lithuania in 2010 to more than two million 
observations in the Czech Republic in 2014. Summary statistics across countries and years are presented in Table 1.

Table 1: Summary statistics

(a) Number of observations

\begin{tabular}{|c|c|c|c|c|c|c|c|c|c|}
\hline year & Bulgaria & Czechia & Estonia & Hungary & Lithuania & Latvia & Poland & Romania & Slovakia \\
\hline 2002 & 151384 & 1025637 & & & 136240 & & 630357 & 229879 & 418835 \\
\hline 2006 & 163139 & 1917859 & 114867 & 677272 & 115088 & 272333 & 640788 & 247843 & 671927 \\
\hline 2010 & 175925 & 1952429 & 109081 & 782600 & 26135 & 199266 & 669313 & 263523 & 769327 \\
\hline 2014 & 168661 & 2153093 & 112771 & 771657 & 31116 & 153808 & 709230 & 271121 & 869849 \\
\hline \multicolumn{10}{|c|}{ (b) Number of firms } \\
\hline year & Bulgaria & Czechia & Estonia & Hungary & Lithuania & Latvia & Poland & Romania & Slovakia \\
\hline 2002 & 2454 & 2289 & & & 5915 & & 13403 & 8870 & 1391 \\
\hline 2006 & 4596 & 11673 & 2628 & 13917 & 5305 & 7641 & 13979 & 10778 & 2971 \\
\hline 2010 & 5187 & 11193 & 2502 & 13681 & 1364 & 5261 & 14423 & 12161 & 4739 \\
\hline 2014 & 4904 & 12159 & 2348 & 12638 & 1628 & 3688 & 14608 & 12075 & 5698 \\
\hline \multicolumn{10}{|c|}{ (c) Mean of hourly earnings (EUR) } \\
\hline year & Bulgaria & Czechia & Estonia & Hungary & Lithuania & Latvia & Poland & Romania & Slovakia \\
\hline 2002 & 0.79 & 2.78 & & & 1.85 & & 3.38 & 1.03 & 1.92 \\
\hline 2006 & 1.12 & 4.19 & 3.57 & 3.50 & 2.79 & 2.67 & 4.12 & 1.84 & 3.08 \\
\hline 2010 & 2.04 & 5.38 & 4.90 & 4.32 & 3.84 & 3.95 & 5.18 & 2.52 & 4.70 \\
\hline 2014 & 2.35 & 5.30 & 5.79 & 4.45 & 4.21 & 4.45 & 5.63 & 2.76 & 5.29 \\
\hline
\end{tabular}

Data: European Structure of Earnings Survey.

Panel $\mathrm{C}$ in Table 1 summarises the distribution and the changes in average hourly gross wages in the CEE countries between 2002 and 2014. We can see that wages were lowest in the late EU entrants, Romania and Bulgaria; and were, on average, twice as high in the Czech Republic, Estonia, Slovakia, and Poland, where they exceeded five euros per hour in 2014. All of the CEE countries recorded substantial increases in average earnings over the analysed period. It should be noted, however, that in most of these countries (particularly those outside of the Eurozone or currency board systems), these increases reflect not only changes in real wages, but also the strengthening of currencies.

Our baseline measure of wages is hourly gross wages, expressed in euros. This measure includes earnings, earnings related to overtime, special payments for shift work, social security contributions, and taxes; but it does not include annual bonuses and allowances not paid at each period. We use the variance of log hourly wages as our measure of wage inequality. This 
is a common statistical measure of dispersion, and, unlike other popular measures of inequality such as the Gini coefficient and the 90-10 wage gap, the variance is additively decomposable into the between-firm component and the within-firm component. We use log wages because the variance of log wages is a mean independent measure (unlike the variance of wages, see Atkinson (1970)). The trends in changes in wage inequality based on Gini and Atkinson measures are very similar to the trends in changes in the variance of wages (Table A.1 and A.2 in the Appendix).

\section{Methodological approach}

Our analysis is carried out in two main steps. First, we analyse levels of and changes in wage inequality in each country over time, and determine the respective contributions of the withinfirm component and the between-firm component to total wage inequality. In the second step, we investigate the determinants of the levels of and the changes in wage inequality over time.

We start the first part of our analysis by normalising wages for each year and country, such that individual wages are defined as $\hat{w}_{i t}=\log \left(100 * \frac{w_{i t}}{\bar{w}_{t}}\right)$, where $w_{i t}$ denotes individual hourly wage and $\bar{w}_{t}$ is average hourly wage in a given year $t$. We then calculate the variance of log wages for each country and each year.

For each country, we analyse to what extent the level of overall wage inequality and its changes are determined by the within-firm and the between-firm wage inequality, following the methodology applied by Lazear and Shaw (2009) and Barth et al. (2016). We decompose the overall variance of normalized log wages $\left(\operatorname{Var}\left(\hat{w}_{i t}\right)\right)$ into the within-firm component $(\operatorname{Var}($ within $))$, and the between-firm component (Var(between)). Thus, the variance decomposition of normalised log wages, $\operatorname{Var}\left(\hat{w}_{i t}\right)=\operatorname{Var}($ within $)+\operatorname{Var}($ between $)$, is given by the following equation:

$$
\operatorname{Var}\left(\hat{w_{i t}}\right)=\frac{1}{N_{t}} \sum_{i}\left(\hat{w_{i t}}-\hat{\bar{w}}_{t}\right)^{2}=\frac{1}{N_{t}} \sum_{j} \sum_{i \in j}\left(\hat{w_{i t}}-\hat{w_{j t}}\right)^{2}+\frac{1}{N_{t}} \sum_{j} N_{j t}\left(\hat{\overline{w_{j t}}}-\hat{\hat{w}_{t}}\right)
$$


where $\hat{\bar{w}}_{t}$ is the average normalised log wage in year $t$ in a given country, $\hat{\overline{w_{j}}}$ denotes the average normalised log wage for workers in firm $j$ in year $t, N_{t}$ is the number of all workers in year $t$ and $N_{j t}$ is the number of workers in firm $j$ in year $t$.

We also repeat the above analysis, but while looking at residual wage inequality; that is, the wage inequality that remains after the workers' and workplaces' observable characteristics are accounted for. First, for each year and country, we estimate a standard Mincerian wage equation of the following form:

$$
\hat{w}_{i}=\beta_{0}+\beta_{1} X_{i}+\beta_{2} X_{j}+\epsilon_{i}
$$

where $X_{i}$ is a set of individual and job characteristics, such as age, gender, education, occupation, type of contract; and $X_{j}$ is a set of firm characteristics, such as sector and the enterprise's forms of economic and financial control. We also account for peer effects (share of female workers, share of workers with tertiary education, share of workers aged 50 or older, and share of workers with tenure of less than two years) to capture more firm heterogeneity (Card \& De La Rica, 2006). Next, we calculate the residuals from the estimated model and analyse the variance of the obtained residuals. In other words, the residual variance is the variance of the unexplained component of wages.

While the exercises above provide us with a broad picture of the aggregate wage dispersion trends, they give us little insight into the determinants of these trends. Several recent studies have tried to distinguish the individual determinants of wage inequality (associated with gender, age, job experience) from job and firm characteristics (Barth et al., 2016; Handwerker \& Spletzer, 2016). To add to this line of research, we estimate in the second step the variance of wages as a function of worker and firm characteristics (the same characteristics as in the Mincerian equation above). To this end, we use the recentered influence function regression, which calculates the partial effect of a small change in the distribution of covariates on the distributional statistic of interest (Firpo et al., 2018), which in our case is the variance. In other words, we calculate the recentered influence function value for each observation according to the following formula:

$$
\operatorname{RIF}\left(\hat{w_{i t}}\right)=\left(\hat{w_{i t}}-\hat{\bar{w}}_{t}\right)^{2}
$$


Next, we estimate the following model for each country and each year:

$$
R I F\left(\hat{w}_{i t}\right)=\beta_{0}+\beta_{1} X_{i t}+\beta_{2} X_{j t}+\epsilon_{i t}
$$

The notation is the same as in Equation (2). We obtain the estimated partial effects of small changes in the distribution of selected variables on the variance of normalised log wages for each country and for each year. Thus, we can observe differences in the magnitude of the effects over time. Furthermore, to gain a better understanding of the determinants of changes in inequality over time, we use the standard Blinder-Oaxaca (BO) method to decompose the changes in the variance of log wages into changes in endowments, coefficients from the RIF regression $\beta_{0}, \beta_{1}, \beta_{2}$ and their interactions. The $\mathrm{BO}$ framework is conventionally used to decompose changes in the mean, but the Fortin et al. (2018) extension makes it possible to perform a $\mathrm{BO}$ type of decomposition on the variance. The decomposition is given by the following equation:

$$
\begin{array}{r}
\operatorname{Var}\left(w_{i, \hat{2014}}\right)-\operatorname{Var}\left(w_{i, \hat{2006}}\right)=\beta_{2006}\left(\bar{X}_{2014}-\bar{X}_{2006}\right) \\
+\left(\beta_{2014}-\beta_{2006}\right) \bar{X}_{2006} \\
+\left(\bar{X}_{2014}-\bar{X}_{2006}\right) *\left(\beta_{2014}-\beta_{2006}\right)
\end{array}
$$

The first term reflects changes in the variance driven by changes in the covariates $\left(\bar{X}_{2014}-\right.$ $\bar{X}_{2006}$ ), assuming that the coefficients remained at the 2006 level. The second term captures the change in the coefficients $\left(\beta_{2014}-\beta_{2006}\right)$, assuming that the covariates remained at the 2006 level. The third term is the residual; i.e., it is an interaction term that accounts for the fact that differences in endowments and coefficients changed simultaneously.

\section{Results}

\subsection{Overall wage dispersion and its changes}

Over the study period, levels of wage inequality varied substantially across the CEE countries (Table 2). In 2014, the lowest wage inequality levels were observed in the Czech Republic and Slovakia (where the variance of log wages amounted to 0.23 ), while the highest wage inequality 
Table 2: Variance of log wages

\begin{tabular}{cccccccccc} 
year & Bulgaria & Czechia & Estonia & Hungary & Lithuania & Latvia & Poland & Romania & Slovakia \\
\hline 2002 & 0.34 & 0.19 & & & 0.37 & & 0.34 & 0.42 & 0.25 \\
2006 & 0.33 & 0.21 & 0.28 & 0.29 & 0.36 & 0.46 & 0.36 & 0.42 & 0.24 \\
2010 & 0.33 & 0.23 & 0.28 & 0.30 & 0.31 & 0.34 & 0.31 & 0.38 & 0.23 \\
2014 & 0.33 & 0.23 & 0.27 & 0.29 & 0.27 & 0.31 & 0.32 & 0.36 & 0.23 \\
\multicolumn{2}{c}{ Data: European Structure of Earnings Survey. } & & & & & &
\end{tabular}

level was observed in Romania (0.36). When we compare the wage inequality levels in the CEE countries to those in the more advanced European countries (Table A.7), we see that the levels in the Czech Republic and Slovakia were similar to the level in the Netherlands, and that the high variance of wages in Romania corresponded to the level of wage inequality in Portugal (where wages were the most dispersed among EU countries, if measured with the D9/D1 decile dispersion (Eurostat, 2014)). The average level of the variance of log wages observed in the CEE countries was around three times higher than it was in the two Scandinavian countries in our study sample (Norway and Sweden). All in all, we find that wages were, on average, more unequal in the CEE countries than in the older EU member states; a result that is confirmed by the Eurostat D9/D1 dispersion statistics.

There were substantial changes in the wage inequality patterns in the CEE countries between the early to mid-2000s and 2014 (Table 2). These changes included a slight increase in the level of wage inequality in the Czech Republic, the CEE country that had the lowest initial level; there, the variance of $\log$ wages increased from 0.19 in 2002 to 0.23 in 2014 . Over the same period, the levels of wage dispersion decreased in the CEE countries that had high initial wage inequality levels. The variance of log wages decreased the most in Latvia (from 0.46 in 2006 to 0.31 in 2014), Romania (from 0.42 in 2006 to 0.36 in 2014), and Lithuania (from 0.37 in 2002 to 0.27 in 2014). Wage inequality levels remained stable in Bulgaria, Estonia, Hungary, and Slovakia. The data suggest that the sharpest declines in wage inequality levels occurred after 2006 (between 2006 and 2010, in particular), possibly as a result of post-crisis adjustments. When we look at the 2002-2006 sub-period (during which seven of the nine CEE countries we analyse entered the European Union), we observe hardly any changes in the overall wage dispersion patterns - though it should be noted that we have information for only a few of the CEE countries in this period. In sum, the differences in the levels of wage dispersion among 
Figure 1: Overall variance of log wages: 2002-2014
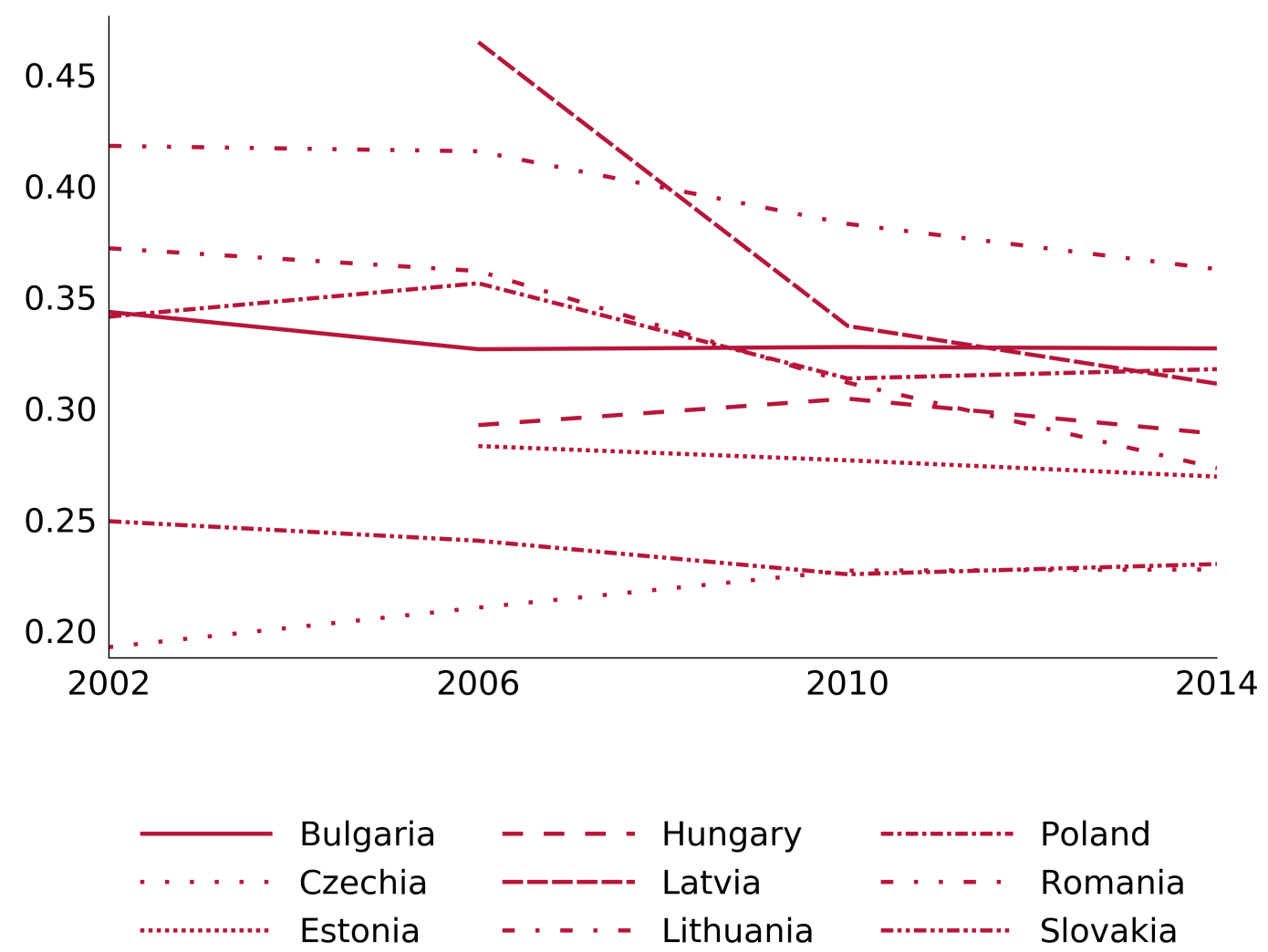

Note: Figure shows variance of normalised log gross hourly wages.

Data: European Structure of Earnings Survey. 
Table 3: Contribution of the within component to level and change in variance of log wages

\begin{tabular}{lcc} 
Level 2006 & $\begin{array}{c}\text { Change 2006-2014 } \\
\text { (percent) }\end{array}$ & 70 \\
\hline Estonia & 60 & 16 \\
Czechia & 55 & 19 \\
Slovakia & 50 & 29 \\
Lithuania & 49 & 25 \\
Hungary & 48 & 46 \\
Latvia & 47 & 35 \\
Poland & 44 & 56 \\
Romania & 36 & 51
\end{tabular}

Note: the first column shows the contribution of the within-firm component to the level of the variance of $\log$ wages in $2006\left(\frac{\operatorname{Var}\left(\text { within }_{2006}\right)}{\operatorname{Var}\left(w_{i}, \hat{2} 006\right)}\right)$. The unreported between component is $100 \%$ minus the reported within component. The second column shows the contribution of the within component to the change of the variance $\left(\frac{\mid \Delta \operatorname{Var}(\text { within }) \mid}{(\mid \Delta \operatorname{Var}(\text { within })|+| \Delta \operatorname{Var}(\text { between }) \mid)}\right)$.

Data: European Structure of Earnings Survey.

the CEE countries narrowed considerably in the 2000s and the early 2010s (see Figure 1).

\subsection{The role of between- and within-firm wage inequality}

The overall wage inequality at the country level arises from the dispersion in average wages between firms, and from the inequality in wages that exists within firms. Thus, as we discussed in the methodological section, we can decompose overall wage inequality into two components: within-firm and between-firm wage inequality. Tables 3 and 4 summarise the results of such an exercise.

The CEE countries differed primarily with respect to between-firm wage inequality, as this component explained most of the existing differences in the total wage inequality levels between countries (see Table 4). In 2014, within-firm wage inequality varied from 0.11 in the Czech Republic to 0.14 in Estonia, Hungary, Latvia, and Poland; while between-firm wage inequality ranged from 0.11 in the Czech Republic and Slovakia to 0.24 in Romania. Thus, between-firm wage inequality was the main contributor to differences in the levels of total wage inequality among the CEE countries. The countries with high levels of total wage inequality 
Table 4: Variance decomposition

(a) Within-firm variance of log wages

\begin{tabular}{cccccccccc} 
year & Bulgaria & Czechia & Estonia & Hungary & Lithuania & Latvia & Poland & Romania & Slovakia \\
\hline 2002 & 0.10 & 0.11 & & & 0.18 & & 0.15 & 0.16 & 0.12 \\
2006 & 0.09 & 0.12 & 0.17 & 0.14 & 0.18 & 0.22 & 0.16 & 0.15 & 0.12 \\
2010 & 0.10 & 0.11 & 0.15 & 0.14 & 0.18 & 0.16 & 0.15 & 0.14 & 0.11 \\
2014 & 0.11 & 0.11 & 0.14 & 0.14 & 0.15 & 0.15 & 0.14 & 0.12 & 0.12
\end{tabular}

Data: European Structure of Earnings Survey.

(b) Between-firm variance of log wages

\begin{tabular}{cccccccccc} 
year & Bulgaria & Czechia & Estonia & Hungary & Lithuania & Latvia & Poland & Romania & Slovakia \\
\hline 2002 & 0.24 & 0.09 & & & 0.19 & & 0.19 & 0.26 & 0.13 \\
2006 & 0.23 & 0.09 & 0.11 & 0.15 & 0.18 & 0.25 & 0.20 & 0.26 & 0.12 \\
2010 & 0.22 & 0.12 & 0.13 & 0.16 & 0.14 & 0.18 & 0.17 & 0.24 & 0.11 \\
2014 & 0.22 & 0.12 & 0.12 & 0.15 & 0.12 & 0.17 & 0.18 & 0.24 & 0.11
\end{tabular}

Data: European Structure of Earnings Survey.

(Romania, Bulgaria) also had much higher levels of between-firm wage inequality than the countries with low levels of total wage inequality (the Czech Republic, Slovakia), whereas the levels of within-firm wage inequality in these two groups of countries were more similar. The share of within-firm wage inequality in total wage inequality varied from $33 \%$ in Bulgaria to $55 \%$ in Lithuania (in 2014). These patterns appear to be similar to those observed in the four Western European countries we analyse: in the Netherlands, Norway, Portugal, and Sweden, the levels of between-firm wage inequality varied more than the levels of within-firm wage inequality.

In the CEE countries, between-firm wage inequality was both higher and more dispersed than within-firm wage inequality in the early to mid-2000s as well. Among the CEE countries for which 2002 data are available, within-firm wage inequality varied in 2002 from 0.11 in the Czech Republic to 0.18 in Lithuania, while the variance of wages between firms in 2002 ranged from a low of 0.09 in the Czech Republic to 0.26 in Romania. Thus, even in the early 2000s, between-firm wage inequality accounted for the majority of the total wage inequality in all of the CEE countries except for Estonia and the Czech Republic. It is important to note, however, that there was no single pattern of changes over time. For instance, Romania saw a decrease in both within-firm and between-firm wage inequality, but the decline was greater in the former component than in the latter. By contrast, in Lithuania, the percentage decrease in the between-firm variance of wages was higher than the decline in the variance of 
wages within firms. In most of the CEE countries, both within-firm and between-firm wage inequality decreased over the study period, but the between-firm component was the main driver of the changes in wage inequality levels between 2006-2014 in most CEE countries (see Table 3). In Romania, Bulgaria, and Estonia, the within-firm component contributed most to the changes in the overall wage inequality.

In terms of both the absolute level and the share of total wage inequality, between-firm wage inequality was generally higher in countries with higher levels of the overall variance of wages. Interestingly, this was also the case in the Western European countries (see Table A.7 in the Appendix, Card et al. (2013) for Germany and Barth et al. (2016) for the US). In both Bulgaria and Portugal, between-firm wage inequality explained around two-thirds of total wage inequality. This component played a smaller role in the Netherlands, where the share of between-firm wage inequality was similar to the average level observed among the CEE countries; and it played an even smaller role in Sweden, where between-firm wage inequality accounted for only one-third of total wage inequality.

\subsection{Residual variance}

We now check whether our findings are robust after controlling for observed worker and firm characteristics. We estimate the Mincerian wage equation (equation (2)) and then calculate variance of the residuals, and decompose this residual variance into within-firm and betweenfirm components.

Residual wage inequality accounted for around 40-50\% of overall wage inequality (see Table 5), which means that the observable characteristics of workers and firms explained around one-half of wage inequality in the CEE countries. Moreover, when we look at residual wage inequality rather than total wage inequality, we see that the share of the within-firm variance is much higher. Within-firm residual wage inequality explained $42 \%$ of total residual wage inequality in Bulgaria and Romania, 60-70\% in most other CEE countries, and a maximum value of $75 \%$ in Slovakia. The share of within-firm residual wage inequality was also higher in countries with lower levels of overall wage inequality, and was lower in high-inequality countries like 
Table 5: Residual variance decomposition

(a) Total residual variance of log wages

\begin{tabular}{cccccccccc} 
year & Bulgaria & Czechia & Estonia & Hungary & Lithuania & Latvia & Poland & Romania & Slovakia \\
\hline 2002 & 0.18 & 0.10 & & & 0.22 & & 0.15 & 0.21 & 0.14 \\
2006 & 0.17 & 0.10 & 0.14 & 0.14 & 0.22 & 0.31 & 0.15 & 0.21 & 0.12 \\
2010 & 0.16 & 0.11 & 0.12 & 0.13 & 0.15 & 0.20 & 0.14 & 0.19 & 0.11 \\
2014 & 0.16 & 0.10 & 0.13 & 0.13 & 0.14 & 0.18 & 0.14 & 0.18 & 0.12
\end{tabular}

Note: Table shows the decomposition of residual variance of normalised log gross hourly wages. The residuals are calculated from the estimated Mincerian wage equation that includes worker and firm characteristics.

Data: European Structure of Earnings Survey.

(b) Within-firm residual variance of log wages

\begin{tabular}{cccccccccc} 
year & Bulgaria & Czechia & Estonia & Hungary & Lithuania & Latvia & Poland & Romania & Slovakia \\
\hline 2002 & 0.06 & 0.05 & & & 0.11 & & 0.07 & 0.09 & 0.07 \\
2006 & 0.05 & 0.06 & 0.09 & 0.07 & 0.11 & 0.14 & 0.08 & 0.08 & 0.07 \\
2010 & 0.06 & 0.06 & 0.07 & 0.07 & 0.09 & 0.10 & 0.08 & 0.07 & 0.06 \\
2014 & 0.06 & 0.06 & 0.09 & 0.08 & 0.08 & 0.10 & 0.08 & 0.07 & 0.07
\end{tabular}

Note: Table shows the decomposition of residual variance of normalised log gross hourly wages. The residuals are calculated from the estimated Mincerian wage equation that includes worker and firm characteristics.

Data: European Structure of Earnings Survey.

(c) Between-firm residual variance of log wages

\begin{tabular}{cccccccccc} 
year & Bulgaria & Czechia & Estonia & Hungary & Lithuania & Latvia & Poland & Romania & Slovakia \\
\hline 2002 & 0.12 & 0.04 & & & 0.11 & & 0.08 & 0.12 & 0.07 \\
2006 & 0.11 & 0.04 & 0.05 & 0.07 & 0.11 & 0.17 & 0.07 & 0.12 & 0.06 \\
2010 & 0.10 & 0.05 & 0.05 & 0.06 & 0.06 & 0.10 & 0.06 & 0.11 & 0.05 \\
2014 & 0.10 & 0.04 & 0.05 & 0.05 & 0.05 & 0.09 & 0.06 & 0.11 & 0.05
\end{tabular}

Note: Table shows the decomposition of residual variance of normalised log gross hourly wages. The residuals are calculated from the estimated Mincerian wage equation that includes worker and firm characteristics.

Data: European Structure of Earnings Survey.

Bulgaria and Romania, where between-firm (residual) wage inequality was relatively high. These patterns are in line with those observed for the overall wage levels. Thus, while a large share of wage inequality was attributable to observable heterogeneity among workers, it appears that various levels of firm-specific wage premia drove between-firm wage inequality, as well as the differences in the role and the size of this component across the CEE.

\subsection{Microeconomic determinants of wage inequality and its changes over time}

A number of micro-level factors affect the degree of wage dispersion among workers. Human capital and skills determine differences in productivity levels, which are reflected in differences in wage levels. Job characteristics, such as the type of contract and the occupation, also affect wages. Moreover, it is likely that in the CEE countries, increased flexibility in the use of non-standard employment contracts (Broughton et al., 2006) and job polarisation trends 
(Hardy, Keister, \& Lewandowski, 2016) have resulted in changes in the wage distribution. There are also firm-level characteristics that determine pay setting schemes, such as sectoral affiliation (Barth et al. (2016)). Peer effects, such as the share of workers in a company who are older or female, may also influence the level of wages and their distribution. Using the RIF regression approach presented in the methodology section, we aim to capture the potential contributions of a set of individual-, job-, and firm-level characteristics to the observed levels of wage inequality. We also decompose changes over time in order to show how the roles these characteristics played changed over time and across countries.

Four interesting observations stand out when we look at the results of the RIF regressions (Tables A.9-A.13). First, in all of the countries studied, we see a strong relationship between the occupation in which an individual works and his/her contribution to wage inequality. In particular, workers in managerial positions (ISCO 1) were much more likely to contribute to wage inequality than workers in sales and services. Bulgaria and Romania again appear to be outliers, as in these countries professionals (ISCO 2) also contributed positively to wage inequality. Second, we observe that sectoral affiliation was an important determinant of wage inequality, with financial and insurance services contributing the most (and manufacturing contributing the least) to increased levels in all countries. Third, we find that peer effects matter a lot: in all of the countries and years analysed, workplaces with large shares of tertiary-educated workers contributed substantially to increased wage inequality, while workplaces with large shares of older workers contributed to decreased wage inequality, all other things being equal. At the same time, we see no obvious link between a worker's age and educational attainment and his/her contribution to wage inequality. Fourth, we find that public sector workplaces had lower levels of wage inequality.

Turning to the time dimension, we observe that the magnitude of the effects changed little over time. In most of the countries studied, the positive effect of age on the variance of log wages increased over time. This change was likely related to the ageing of the workforce and increasing employment rates among older workers (whose wages tended to be more unequal). In most countries, the correlation between managerial occupation and wage inequality was strengthened or remained strong (Latvia, Poland, Estonia). All of the countries experienced 
Figure 2: Blinder-Oaxaca decomposition of the changes in the variance of log wages between 2006 and 2014

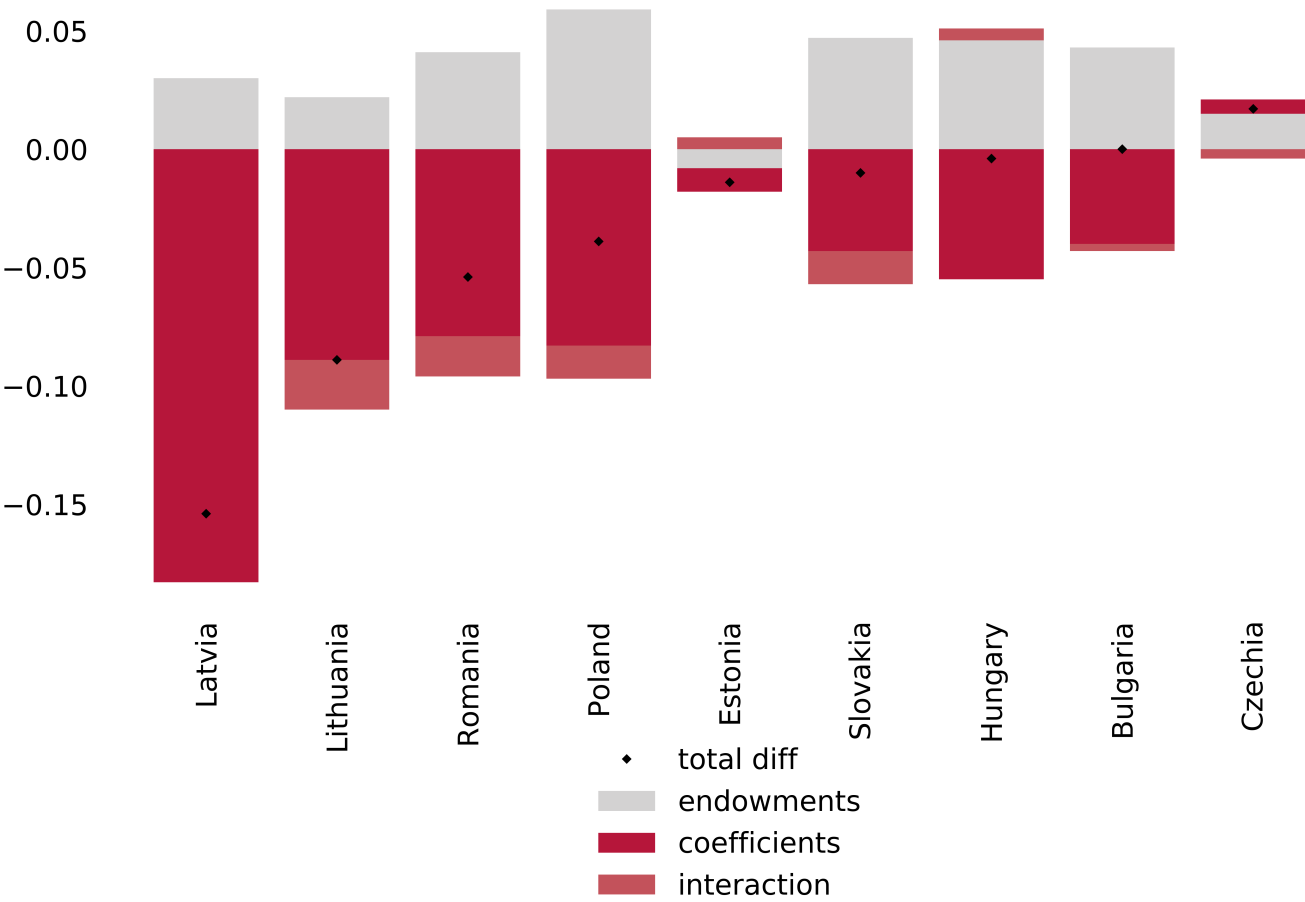

Note: Figure shows the results of the Blinder-Oaxaca decomposition of changes in variance of normalised log gross hourly wages between 2006 and 2014 based on RIF regressions.

Data: European Structure of Earnings Survey.

a decreasing effect of tertiary education on the variance of wages.

In order to better capture changes in the determinants of wage inequality over time, we decompose the above estimates using a Blinder-Oaxaca approach, as we discussed in the methodology section. This approach allows us to distinguish between the impact of changes in endowments (i.e., the structure of workers with respect to their personal characteristics and the characteristics of their workplaces) and coefficients (i.e., returns to these characteristics) on the change in the variance of log wages between 2006 and 2014. The analysis is performed for each country separately. We find that changes in endowments - that is, changes in the structure of workers with respect to their own characteristics and those of their firms - contributed to increases in wage inequality, while changes in coefficients contributed to decreases in inequality (see Figure 2). Thus, the overall observed pattern of decreasing wage inequality resulted from larger 
changes in coefficients than in endowments. The Czech Republic was the only country where changes in endowments led to a (slight) increase in wage inequality. In Bulgaria and Hungary, inequality-increasing changes in endowments were offset by changes in returns, resulting in stable wage inequality levels. The largest changes in the structure of workers were in Poland, and these changes would have led to increased inequality had they not been offset by substantial decreases in coefficients. The largest inequality-decreasing changes in coefficients were in Latvia, where the variance of wages decreased substantially.

The detailed results of the $\mathrm{BO}$ decomposition provide us with interesting insights into the micro-determinants of changes in inequality (Tables A.14-A.18 in the Appendix). First, we see that the decline in returns to tertiary education was an important factor associated with decreasing wage inequality. In Poland, Latvia, Lithuania, and Hungary this decline in returns helped to offset the growing share of tertiary-educated workers and co-workers (who contributed to increasing wage inequality, all other things being equal). Second, the returns to age became more inequality-increasing in all of the countries except for Poland (see Table A.16). Interestingly, the changes in the returns to the sectoral affiliation of workers were rather small. Finally, in all of the countries that experienced significant decreases in wage inequality (except Lithuania), we observe that changes in the intercept contributed substantially to this trend; these were likely linked to institutional adjustments. This finding suggests that in most of the CEE countries studied, the decrease in wage inequality was partly attributable to factors that were unobserved in our data, and were most likely regulatory changes related to the Great Recession and its aftermath.

Since public sector employment constituted an important share of employment in the CEE countries and contributed to decreases in wage inequality in our study period, we decided to run an additional analysis that included private sector employees only. The results show that in the private sector, as in the total economy, changes in coefficients contributed to decreases in inequality, and changes in endowments contributed to increases in inequality in all of the CEE countries except the Czech Republic. However, the impact of changes in the intercept was much greater in the private sector than in the full sample, as the intercept was the factor that made the largest contribution to the changes in the levels of wage inequality. In other 
respects, however, there were no significant differences in the results of the two RIF regressions (see Tables A.19-A.23 in the Appendix) and the Blinder-Oaxaca decomposition (see Tables A.24-A.28).

\section{Conclusions}

Wage inequality decreased in most Central and Eastern European countries between the early 2000s and the mid-2010s. The Czech Republic, which still has the lowest level of wage inequality in the region, was the only CEE country that saw a slight increase in wage inequality during this period. Thus, the trends observed in the CEE countries stand in stark contrast to the patterns of increasing wage inequality reported in many Western countries. As the decreases in wage inequality in the CEE countries appear to have been concentrated in the 2006-2014 period, the question of what role the Great Recession and the post-crisis adjustments played in these patterns arises.

Our analysis of the determinants of the decreases in wage inequality in the CEE revealed that this trend was primarily driven by falling returns to individual- and firm-level characteristics, and to tertiary education in particular. It is likely that the decreases in wage inequality levels would have been greater if the workforce endowments - especially the increases in shares of university-educated employees - had not changed. Still, a sizeable share of the observed changes resulted from trends that are unexplained, and that likely reflect changes in institutional settings.

We contribute to the ongoing debate on the role firms play in shaping wage inequality with our finding that in both the early 2000s and 2014, wage inequality in CEE was greater between firms than within them. After we accounted for the characteristics of workers and firms and calculated residual wage inequality, we found that the role of the between-firm component was diminished, but still explained most of the cross-country differences in wage inequality. It thus appears that wage inequality was driven to a large extent by where an individual was working, and with whom $\mathrm{s} /$ he was working. Workplace-specific wage premia were linked not only to occupation and sectoral affiliation, but to co-workers' characteristics. Managers working in 
the financial services firms with young, tertiary-educated peers contributed most to increasing wage inequality in all of the CEE countries studied.

We also found that among the CEE countries in our study sample, Bulgaria and Romania are interesting cases that merit further in-depth investigation. Compared to the other countries in the region, these two countries have much higher levels of wage inequality, as well as much higher levels and shares of between-firm wage inequality. These findings suggest that Bulgarian and Romanian firms are more heterogeneous in terms of their productivity levels. Further research is needed to determine whether these countries differ from other countries in the region because they underwent economic restructuring more recently, have lower levels of economic development, and/or entered the EU later.

\section{References}

Abowd, J. M., Kramarz, F., \& Margolis, D. N. (1999). High wage workers and high wage firms. Econometrica, 67(2), 251-333. doi:10.1111/1468-0262.00020

Acemoglu, D., \& Autor, D. H. (2011). Chapter 12 - skills, tasks and technologies: Implications for employment and earnings. In D. Card \& O. Ashenfelter (Eds.), (Vol. 4, pp. 10431171). Handbook of Labor Economics. doi:10.1016/S0169-7218(11)02410-5

Akerman, A., Helpman, E., Itskhoki, O., Muendler, M.-A., \& Redding, S. (2013). Sources of wage inequality. American Economic Review, 103(3), 214-219. doi:10.1257/aer.103.3.214

Alvarez, J., Benguria, F., Engbom, N., \& Moser, C. (2018). Firms and the decline in earnings inequality in brazil. American Economic Journal: Macroeconomics, 10(1), 149-189. doi: $10.1257 /$ mac. 20150355

Antonczyk, D., Fitzenberger, B., \& Sommerfeld, K. (2010). Rising wage inequality, the decline of collective bargaining, and the gender wage gap. Labour Economics, 17(5), 835-847. doi:10.1016/j.labeco.2010.04.008

Appleton, S., Song, L., \& Xia, Q. (2014). Understanding urban wage inequality in china 1988-2008: Evidence from quantile analysis. World Development, 62, 1-13. doi:10.1016/ j.worlddev.2014.04.005

Aristei, D., \& Perugini, C. (2012). Inequality and reforms in transition countries. Economic Systems, 36 (1), 2-10. doi:10.1016/j.ecosys.2011.09.001

Aristei, D., \& Perugini, C. (2014). Speed and sequencing of transition reforms and income inequality: A panel data analysis. Review of Income and Wealth, 60 (3), 542-570. doi:10. 1111/roiw.12090 
Atkinson, A. B. (1970). On the measurement of inequality. Journal of Economic Theory, 2(3), 244-263.

Autor, D. H., Katz, L. F., \& Kearney, M. S. (2006). The polarization of the u.s. labor market. American Economic Review, 96(2), 189-194. doi:10.1257/000282806777212620

Autor, D. H., Katz, L. F., \& Kearney, M. S. (2008). Trends in u.s. wage inequality: Revising the revisionists. Review of Economics and Statistics, 90(2), 300-323. doi:10.1162/rest. 90.2 .300

Autor, D. H., Manning, A., \& Smith, C. L. (2016). The contribution of the minimum wage to us wage inequality over three decades: A reassessment. American Economic Journal: Applied Economics, 8(1), 58-99. doi:10.1257/app.20140073

Barth, E., Bryson, A., Davis, J. C., \& Freeman, R. (2016). It's where you work: Increases in the dispersion of earnings across establishments and individuals in the united states. Journal of Labor Economics, 34(S2), 244-263. doi:10.1086/684045

Bell, B., Bukowski, P., \& Machin, S. (2018). Rent Sharing and Inclusive Growth (CEP Discussion Papers No. dp1584). Centre for Economic Performance, LSE. Retrieved from https://ideas.repec.org/p/cep/cepdps/dp1584.html

Broughton, A., Green, M., Rickard, C., Swift, S., Eichhorst, W., Tobsch, V., ... Tros, F. (2006). Precarious employment in europe: Country case studies. European Parliament.

Card, D., Cardoso, A. R., Heining, J., \& Kline, P. (2018). Firms and labor market inequality: Evidence and some theory. Journal of Labor Economics, 36(S1), 13-70. doi:10.1086/ 694153

Card, D., \& De La Rica, S. (2006). Firm-level contracting and the structure of wages in spain. Industrial and Labor Relations Review, 59(4), 573-592. doi:10.1177/001979390605900403

Card, D., Heining, J., \& Kline, P. (2013). Workplace heterogeneity and the rise of west german wage inequality. The Quarterly Journal of Economics, 128(3), 967-1015. doi:10.1093/ q.je/q.jt006

Du Caju, P., Kátay, G., Lamo, A., Nicolitsas, D., \& Poelhekke, S. (2010). Inter-industry wage differentials in EU countries: What do cross-country time varying data add to the picture? Journal of the European Economic Association, 8(2-3), 478-486. doi:10.1111/ j.1542-4774.2010.tb00518.x

Dustmann, C., Ludsteck, J., \& Schönberg, U. (2009). Revisiting the german wage structure. The Quarterly Journal of Economics, 124(2), 843-881. doi:10.1162/qjec.2009.124.2.843

Eurostat. (2014). D9 d1 dispersion ratio in the eu member states. Retrieved September 21, 2018, from https://ec.europa.eu/eurostat/statistics-explained/index.php?title=File: D9_D1_dispersion_ratio_in_the_EU_Member_States,_2014_update.png

Firpo, S., Fortin, N., \& Lemieux, T. (2018). Decomposing wage distributions using recentered influence function regressions. Econometrics, 6. doi:10.3390/econometrics6020028 
Fortin, N., Green, D. A., Lemieux, T., Milligan, K., \& Riddell, W. C. (2012). Canadian inequality: Recent developments and policy options. Canadian Public Policy, 38(2), 121-145. doi:10.3138/cpp.38.2.121

Gaudecker, H.-M. von. (2014). Templates for reproducible research projects in economics. https: //github.com/hmgaudecker/econ-project-templates.

Ge, S., \& Yang, D. T. (2014). Changes In China'S Wage Structure. Journal of the European Economic Association, 12(2), 300-336. doi:10.1111/jeea.12072

Goldschmidt, D., \& Schmieder, J. F. (2017). The rise of domestic outsourcing and the evolution of the german wage structure. The Quarterly Journal of Economics, 132(3), 1165-1217. doi:10.1093/qje/qjx008

Handwerker, E. W., \& Spletzer, J. R. (2016). The role of establishments and the concentration of occupations in wage inequality. In Inequality: Causes and consequences (Chap. 5, pp. 167-193). doi:10.1108/S0147-912120160000043013

Hardy, W., Keister, R., \& Lewandowski, P. (2016). Educational upgrading, structural change and the task composition of jobs in europe. The Economics of Transition, 26(2), 201231. doi:10.1111/ecot.12145

Helpman, E., Itskhoki, O., Muendler, M.-A., \& Redding, S. (2017). Trade and Inequality: From Theory to Estimation. The Review of Economic Studies, 84(1), 357-405. doi:10. $1093 / \mathrm{restud} / \mathrm{rdw} 025$

Kelly, T., Liaplina, A., Tan, S. T., \& Winkler, H. (2017). Reaping digital dividends: Leveraging the internet for development in europe and central asia. doi:10.1596/978-1-4648-1025-1

Krishna, P., Poole, J. P., \& Senses, M. Z. (2012). Trade, Labor Market Frictions, and Residual Wage Inequality across Worker Groups. American Economic Review, 102(3), 417-423. doi:10.1257/aer.102.3.417

Krueger, A. B., \& Summers, L. H. (1988). Efficiency wages and the inter-industry wage structure. Econometrica, 56(2), 259-293. doi:10.2307/1911072

Lazear, E. P., \& Shaw, K. L. (2009). The structure of wages: An international comparison. doi:10.7208/chicago/9780226470511.001.0001

Lemieux, T. (2006). Increasing residual wage inequality: Composition effects, noisy data, or rising demand for skill? American Economic Review, 96(3), 461-498. doi:10.1257/aer. 96.3 .461

Machin, S. (2016). Rising wage inequality, real wage stagnation and unions. In Inequality: Causes and consequences (Chap. 9, pp. 329-354). doi:10.1108/S0147-912120160000043017

Martins, P. S. (2004). Industry wage premia: evidence from the wage distribution. Economics Letters, 83(2), 157-163. doi:10.1016/j.econlet.2003.11.002

Messina, J., \& Silva, J. (2017). Wage inequality in latin america: Understanding the past to prepare for the future. doi:10.1596/978-1-4648-1039-8 
Milanovic, B., \& Ersado, L. (2012). Reform and inequality during the transition: An analysis using panel household survey data, 1990-2005. In Economies in transition (pp. 84-108). doi: $10.1057 / 9780230361836 \_4$

Mysíková, M., \& Večerník, J. (2018). Personal Earnings Inequality and Polarization: The Czech Republic in Comparison with Austria and Poland. Eastern European Economics, 56(1), 57-80. doi:10.1080/00128775.2017.1402685

Pryor, F. L. (2014). A note on income inequality in east and central europe. Comparative Economic Studies, 56(1), 42-51. doi:10.1057/ces.2013.31

Song, J., Price, D. J., Guvenen, F., Bloom, N., \& Wachter, T. von. (2019). Firming up inequality. The Quarterly Journal of Economics, 134(1), 1-50. doi:10.1093/qje/qjy025

Tyrowicz, J., \& Smyk, M. (2019). Wage inequality and structural change. Social Indicators Research, 141(2), 503-538. doi:10.1007/s11205-018-1846-y

\section{A Annex}

Table A.1: Gini coefficient

\begin{tabular}{cccccccccc} 
year & Bulgaria & Czechia & Estonia & Hungary & Lithuania & Latvia & Poland & Romania & Slovakia \\
\hline 2002 & 0.34 & 0.26 & & & 0.36 & & 0.34 & 0.38 & 0.30 \\
2006 & 0.35 & 0.27 & 0.31 & 0.32 & 0.35 & 0.39 & 0.35 & 0.38 & 0.30 \\
2010 & 0.35 & 0.28 & 0.30 & 0.33 & 0.32 & 0.34 & 0.33 & 0.37 & 0.28 \\
2014 & 0.36 & 0.28 & 0.30 & 0.32 & 0.31 & 0.33 & 0.34 & 0.37 & 0.29
\end{tabular}

Data: European Structure of Earnings Survey.

Table A.2: Atkinson index $(\epsilon=2)$

\begin{tabular}{cccccccccc} 
year & Bulgaria & Czechia & Estonia & Hungary & Lithuania & Latvia & Poland & Romania & Slovakia \\
\hline 2002 & 0.29 & 0.18 & & & 0.31 & & 0.29 & 0.34 & 0.23 \\
2006 & 0.28 & 0.19 & 0.25 & 0.26 & 0.30 & 0.37 & 0.30 & 0.34 & 0.22 \\
2010 & 0.28 & 0.21 & 0.24 & 0.26 & 0.27 & 0.29 & 0.27 & 0.32 & 0.21 \\
2014 & 0.28 & 0.21 & 0.24 & 0.25 & 0.24 & 0.27 & 0.27 & 0.31 & 0.21
\end{tabular}

Data: European Structure of Earnings Survey.

Table A.3: Variance of log wages: manufacturing and construction

\begin{tabular}{cccccccccc} 
year & Bulgaria & Czechia & Estonia & Hungary & Lithuania & Latvia & Poland & Romania & Slovakia \\
\hline 2002 & 0.38 & 0.19 & & & 0.34 & & 0.30 & 0.36 & 0.22 \\
2006 & 0.31 & 0.18 & 0.25 & 0.31 & 0.35 & 0.45 & 0.31 & 0.33 & 0.23 \\
2010 & 0.29 & 0.19 & 0.24 & 0.29 & 0.28 & 0.31 & 0.25 & 0.32 & 0.20 \\
2014 & 0.30 & 0.19 & 0.22 & 0.25 & 0.24 & 0.29 & 0.26 & 0.28 & 0.20
\end{tabular}

Data: European Structure of Earnings Survey. 
Table A.4: Variance of log wages: market services

\begin{tabular}{cccccccccc} 
year & Bulgaria & Czechia & Estonia & Hungary & Lithuania & Latvia & Poland & Romania & Slovakia \\
\hline 2002 & 0.43 & 0.23 & & & 0.44 & & 0.37 & 0.58 & 0.31 \\
2006 & 0.40 & 0.29 & 0.33 & 0.39 & 0.39 & 0.52 & 0.38 & 0.52 & 0.31 \\
2010 & 0.40 & 0.31 & 0.33 & 0.36 & 0.35 & 0.40 & 0.35 & 0.48 & 0.29 \\
2014 & 0.40 & 0.31 & 0.32 & 0.33 & 0.32 & 0.38 & 0.36 & 0.46 & 0.28
\end{tabular}

Data: European Structure of Earnings Survey.

Table A.5: Variance of log wages: non-market services

\begin{tabular}{cccccccccc} 
year & Bulgaria & Czechia & Estonia & Hungary & Lithuania & Latvia & Poland & Romania & Slovakia \\
\hline 2002 & 0.20 & 0.14 & & & 0.35 & & 0.34 & 0.36 & 0.18 \\
2006 & 0.26 & 0.16 & 0.28 & 0.21 & 0.33 & 0.42 & 0.32 & 0.41 & 0.18 \\
2010 & 0.24 & 0.16 & 0.25 & 0.26 & 0.30 & 0.29 & 0.30 & 0.36 & 0.17 \\
2014 & 0.24 & 0.17 & 0.25 & 0.27 & 0.26 & 0.26 & 0.29 & 0.35 & 0.19
\end{tabular}

Data: European Structure of Earnings Survey.

Table A.6: Summary statistics

(a) Number of observations

\begin{tabular}{ccccc} 
year & Netherlands & Norway & Portugal & Sweden \\
\hline 2002 & 53405 & 518025 & & \\
2006 & 64275 & 869486 & 62438 & 273620 \\
2010 & 91531 & 1257334 & 87516 & 272389 \\
2014 & 79906 & 1346013 & 60977 & 252413
\end{tabular}

(b) Number of firms

\begin{tabular}{ccccc} 
year & Netherlands & Norway & Portugal & Sweden \\
\hline 2002 & 1550 & 10179 & & \\
2006 & 2068 & 17589 & 3346 & 4733 \\
2010 & 2500 & 28897 & 4449 & 4918 \\
2014 & 2180 & 31073 & 2852 & 3650
\end{tabular}

(c) Mean of hourly earnings (EUR)

\begin{tabular}{ccccc} 
year & Netherlands & Norway & Portugal & Sweden \\
\hline 2002 & 15.97 & 22.07 & & \\
2006 & 15.90 & 23.93 & 7.20 & 15.89 \\
2010 & 17.96 & 28.10 & 8.07 & 17.63 \\
2014 & 18.84 & 30.96 & 7.70 & 20.52
\end{tabular}

Data: European Structure of Earnings Survey. 
Table A.7: Variance decomposition

(a) Variance of log wages

\begin{tabular}{ccccc} 
year & Netherlands & Norway & Portugal & Sweden \\
\hline 2002 & 0.21 & & & \\
2006 & 0.28 & 0.12 & 0.42 & 0.09 \\
2010 & 0.27 & 0.12 & 0.40 & 0.09 \\
2014 & 0.23 & 0.12 & 0.35 & 0.09
\end{tabular}

Data: European Structure of Earnings Survey.

(b) Within-firm variance of log wages

\begin{tabular}{ccccc} 
year & Netherlands & Norway & Portugal & Sweden \\
\hline 2002 & 0.13 & & & \\
2006 & 0.18 & 0.06 & 0.16 & 0.06 \\
2010 & 0.17 & 0.06 & 0.16 & 0.06 \\
2014 & 0.11 & 0.06 & 0.14 & 0.06
\end{tabular}

Data: European Structure of Earnings Survey.

(c) Between-firm variance of log wages

\begin{tabular}{ccccc} 
year & Netherlands & Norway & Portugal & Sweden \\
\hline 2002 & 0.08 & & & \\
2006 & 0.10 & 0.05 & 0.26 & 0.03 \\
2010 & 0.10 & 0.05 & 0.24 & 0.03 \\
2014 & 0.12 & 0.06 & 0.20 & 0.03
\end{tabular}

Data: European Structure of Earnings Survey.

Table A.8: Contribution of the within component to variance of log wages

\begin{tabular}{lcc} 
& $\begin{array}{c}\text { Level 2006 } \\
\text { (percent) }\end{array}$ & $\begin{array}{c}\text { Change 2006-2014 } \\
\text { (percent) }\end{array}$ \\
\hline Netherlands & 63 & 77 \\
Norway & 54 & 10 \\
Sweden & 66 & 39 \\
Portugal & 39 & 26
\end{tabular}

Note: the first column shows the contribution of the within-firm component to the level of the variance of $\log$ wages in $2006\left(\frac{\operatorname{Var}\left(\text { within }_{2006}\right)}{\operatorname{Var}\left(w_{i, 2006}\right)}\right)$. The unreported between component is $100 \%$ minus the reported within component. The second column shows the contribution of the within component to the change of the variance $\left(\frac{\mid \Delta \operatorname{Var}(\text { within }) \mid}{(\mid \Delta \operatorname{Var}(\text { within })|+| \Delta \operatorname{Var}(\text { between }) \mid)}\right)$.

Data: European Structure of Earnings Survey. 
Table A.9: Results of RIF regression: Bulgaria and Romania

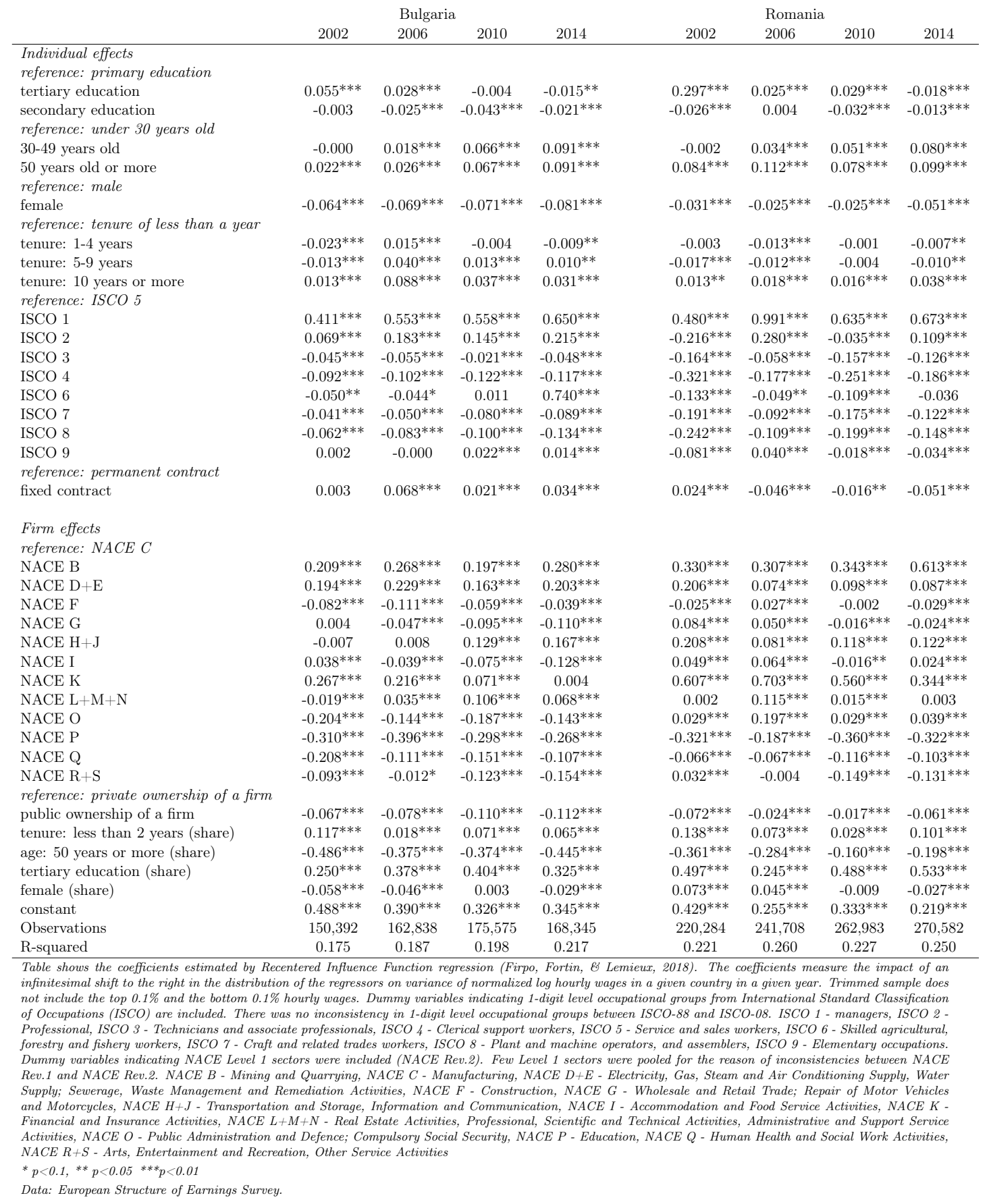


Table A.10: Results of RIF regression: Czechia and Slovakia

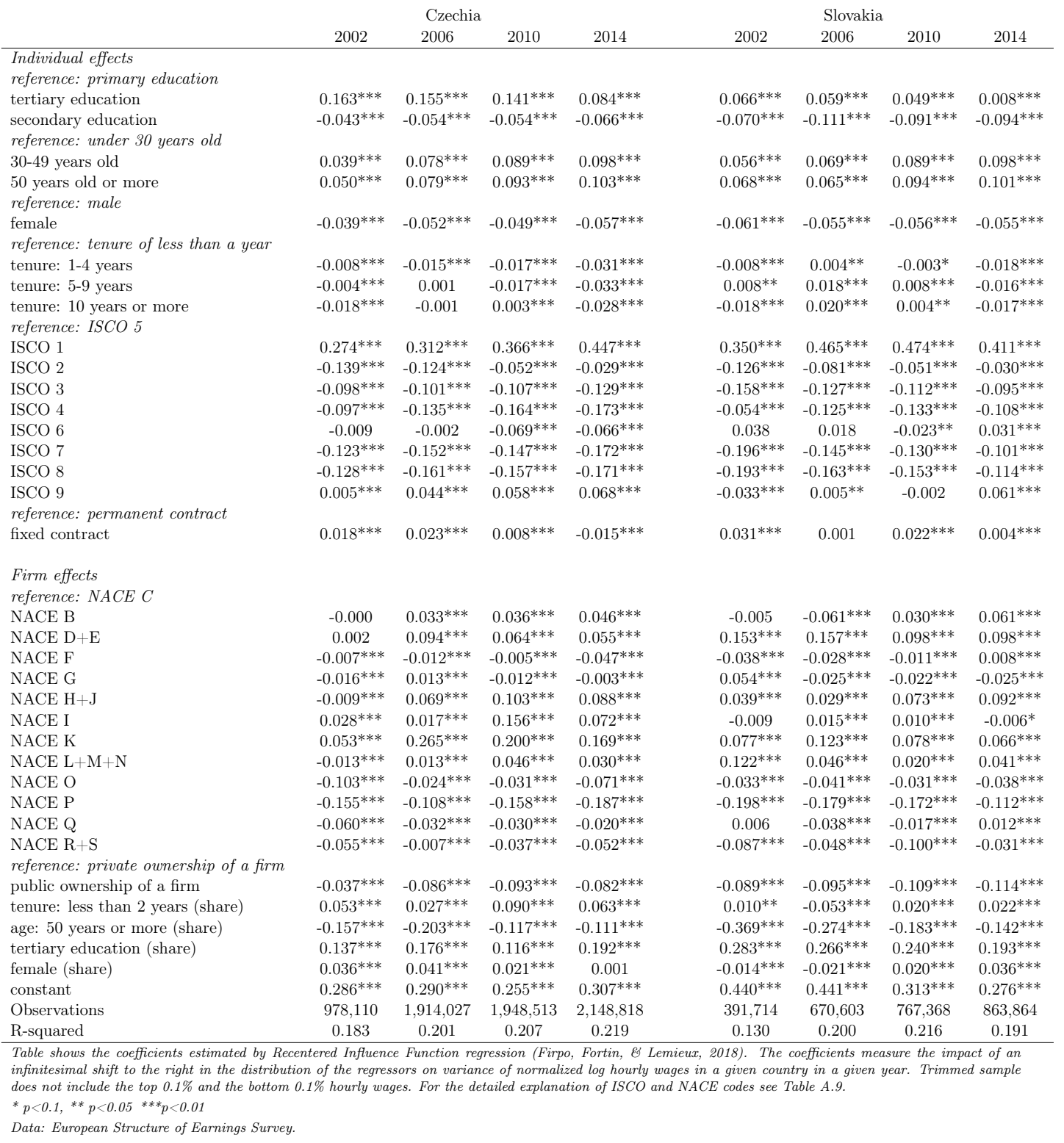


Table A.11: Results of RIF regression: Estonia and Poland

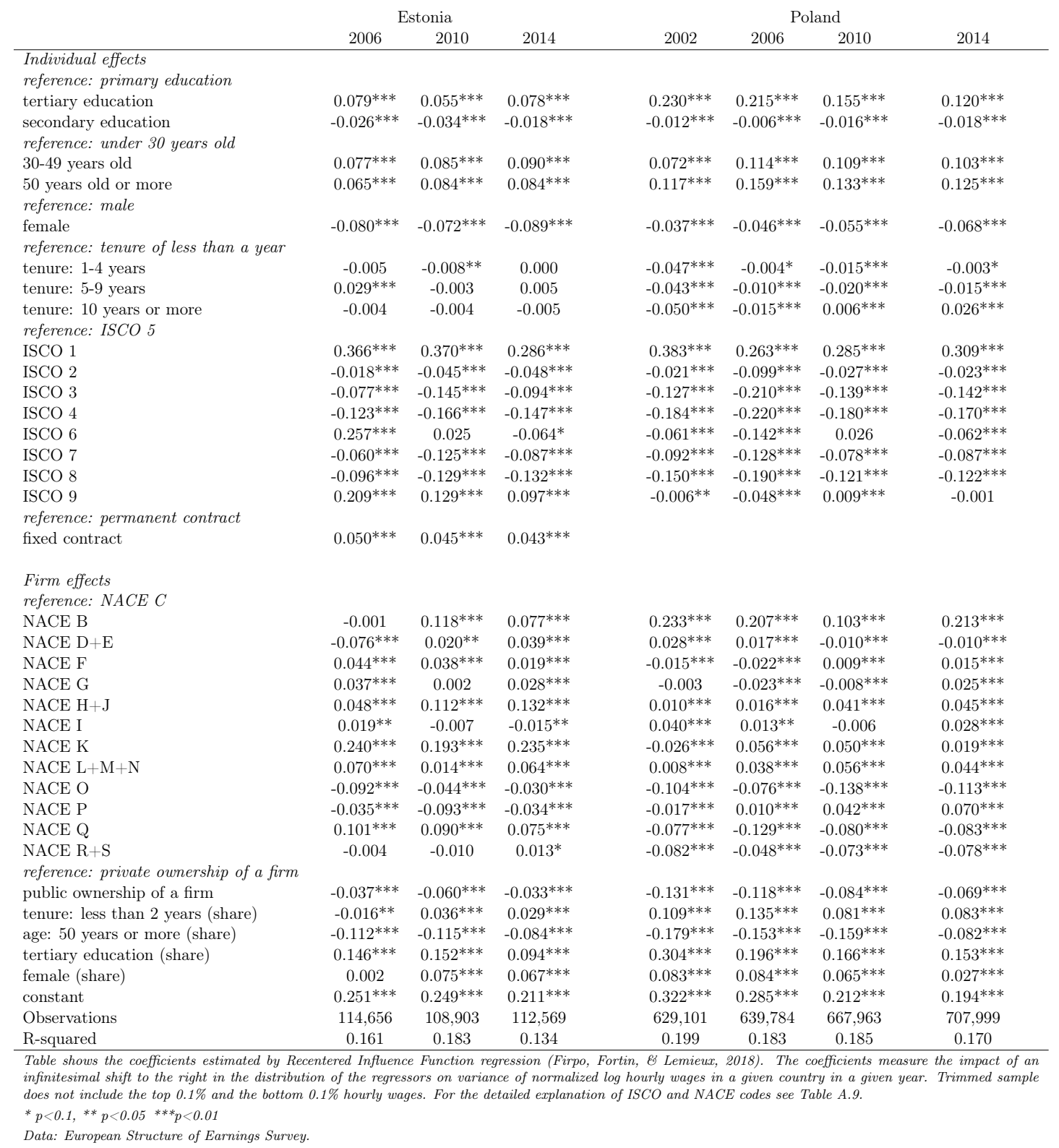


Table A.12: Results of RIF regression: Lithuania and Latvia

\begin{tabular}{|c|c|c|c|c|c|c|c|}
\hline & \multicolumn{4}{|c|}{ Lithuania } & \multicolumn{3}{|c|}{ Latvia } \\
\hline & 2002 & 2006 & 2010 & 2014 & 2006 & 2010 & 2014 \\
\hline \multicolumn{8}{|l|}{ Individual effects } \\
\hline \multicolumn{8}{|l|}{ reference: primary education } \\
\hline tertiary education & $0.139 * * *$ & $0.132^{* * *}$ & $0.061^{* * *}$ & 0.015 & $0.077^{* * *}$ & $0.033^{* * *}$ & 0.000 \\
\hline secondary education & $-0.010^{* *}$ & -0.001 & $-0.043^{* * *}$ & $-0.020^{*}$ & $-0.028^{* * *}$ & $-0.029^{* * *}$ & $-0.032^{* * *}$ \\
\hline \multicolumn{8}{|l|}{ reference: under 30 years old } \\
\hline $30-49$ years old & $0.035^{* * *}$ & $0.066^{* * *}$ & $0.089^{* * *}$ & $0.091^{* * *}$ & $0.079^{* * *}$ & $0.084^{* * *}$ & $0.103^{* * *}$ \\
\hline $\begin{array}{l}50 \text { years old or more } \\
\text { reference: male }\end{array}$ & $0.046^{* * *}$ & $0.074^{* * *}$ & $0.098^{* * *}$ & $0.104^{* * *}$ & $0.070^{* * *}$ & $0.067^{* * *}$ & $0.095^{* * *}$ \\
\hline female & $-0.058^{* * *}$ & $-0.069 * * *$ & $-0.075^{* * *}$ & $-0.085^{* * *}$ & $-0.073^{* * *}$ & $-0.079^{* * *}$ & $-0.067^{* * *}$ \\
\hline \multicolumn{8}{|l|}{ reference: tenure of less than a year } \\
\hline tenure: $1-4$ years & 0.002 & $0.016^{* * *}$ & $-0.028^{* * *}$ & -0.005 & $0.018^{* * *}$ & -0.001 & $0.018^{* * *}$ \\
\hline tenure: $5-9$ years & $0.018^{* * *}$ & $0.054^{* * *}$ & -0.015 & $-0.019 * *$ & $0.052^{* * *}$ & $0.015^{* * *}$ & $0.021^{* * *}$ \\
\hline \multicolumn{8}{|l|}{ reference: ISCO 5} \\
\hline ISCO 1 & $0.310^{* * *}$ & $0.274^{* * *}$ & $0.243^{* * *}$ & $0.457^{* * *}$ & $0.320^{* * *}$ & $0.331^{* * *}$ & $0.322^{* * *}$ \\
\hline ISCO 2 & $-0.029^{* * *}$ & $-0.060^{* * *}$ & $-0.136^{* * *}$ & $-0.048^{* * *}$ & 0.007 & $-0.007^{*}$ & $0.017^{* * *}$ \\
\hline ISCO 3 & $-0.041^{* * *}$ & $-0.060^{* * *}$ & $-0.134^{* * *}$ & $-0.102^{* * *}$ & $-0.100^{* * *}$ & $-0.100^{* * *}$ & $-0.104^{* * *}$ \\
\hline ISCO 4 & $-0.110^{* * *}$ & $-0.129^{* * *}$ & $-0.155^{* * *}$ & $-0.127^{* * *}$ & $-0.121^{* * *}$ & $-0.121^{* * *}$ & $-0.152^{* * *}$ \\
\hline ISCO 6 & 0.028 & $0.159^{* * *}$ & 0.107 & -0.236 & $0.103^{* * *}$ & 0.038 & $0.081^{* * *}$ \\
\hline ISCO 7 & $-0.026^{* * *}$ & $-0.013^{* *}$ & $-0.095^{* * *}$ & $-0.069^{* * *}$ & $-0.034^{* * *}$ & $-0.059^{* * *}$ & $-0.047^{* * *}$ \\
\hline ISCO 8 & $-0.031^{* * *}$ & $-0.058^{* * *}$ & $-0.157^{* * *}$ & $-0.110^{* * *}$ & $-0.038^{* * *}$ & $-0.063^{* * *}$ & $-0.067^{* * *}$ \\
\hline ISCO 9 & $0.085^{* * *}$ & $0.118^{* * *}$ & $0.150^{* * *}$ & $0.091^{* * *}$ & $0.124^{* * *}$ & $0.086^{* * *}$ & $0.086^{* * *}$ \\
\hline \multicolumn{8}{|l|}{ reference: permanent contract } \\
\hline fixed contract & $-0.029^{* * *}$ & $0.052^{* * *}$ & $0.046^{* * *}$ & -0.000 & $0.187^{* * *}$ & $0.064^{* * *}$ & $0.047^{* * *}$ \\
\hline \multicolumn{8}{|l|}{ Firm effects } \\
\hline NACE B & $0.067 * * *$ & 0.020 & -0.060 & $-0.074^{*}$ & $-0.100^{* * *}$ & $-0.111^{* * *}$ & -0.027 \\
\hline NACE D + E & $0.081 * * *$ & $0.072^{* * *}$ & $0.033^{* *}$ & $0.049^{* * *}$ & $0.120^{* * *}$ & $-0.013^{*}$ & 0.003 \\
\hline NACE F & $0.012^{* *}$ & $0.074^{* * *}$ & $-0.027^{* *}$ & $-0.033^{* * *}$ & -0.003 & $-0.032^{* * *}$ & $-0.050^{* * *}$ \\
\hline NACE G & $0.012^{* *}$ & $0.010^{* *}$ & -0.014 & 0.005 & $0.029^{* * *}$ & $-0.029^{* * *}$ & $-0.027^{* * *}$ \\
\hline $\mathrm{NACE} \mathrm{H}+\mathrm{J}$ & $0.086^{* * *}$ & $0.084^{* * *}$ & $0.101^{* * *}$ & $0.081^{* * *}$ & $0.072^{* * *}$ & $0.072^{* * *}$ & $0.092^{* * *}$ \\
\hline NACE I & $0.072^{* * *}$ & $0.064^{* * *}$ & -0.030 & 0.020 & $0.067^{* * *}$ & $0.014^{*}$ & $-0.034^{* * *}$ \\
\hline NACE K & $0.260^{* * *}$ & $0.300^{* * *}$ & $0.212^{* * *}$ & $0.217^{* * *}$ & $0.286^{* * *}$ & $0.281^{* * *}$ & $0.322^{* * *}$ \\
\hline $\mathrm{NACE} \mathrm{L}+\mathrm{M}+\mathrm{N}$ & $-0.022 * * *$ & -0.007 & $0.033^{* * *}$ & $0.031^{* * *}$ & $0.068^{* * *}$ & $-0.023^{* * *}$ & 0.008 \\
\hline NACE O & $0.026^{* * *}$ & $0.059^{* * *}$ & -0.022 & $-0.038^{* * *}$ & $-0.081^{* * *}$ & $-0.186^{* * *}$ & $-0.191^{* * *}$ \\
\hline NACE P & $-0.012^{*}$ & 0.010 & $0.131^{* * *}$ & $0.038^{* * *}$ & 0.002 & $-0.113^{* * *}$ & $-0.146^{* * *}$ \\
\hline NACE Q & $-0.052^{* * *}$ & $0.074^{* * *}$ & $0.107^{* * *}$ & $0.094^{* * *}$ & $0.068^{* * *}$ & -0.008 & $0.036^{* * *}$ \\
\hline NACE $\mathrm{R}+\mathrm{S}$ & $-0.055^{* * *}$ & $-0.022^{* * *}$ & -0.009 & $-0.062^{* * *}$ & 0.002 & $-0.101^{* * *}$ & $-0.089^{* * *}$ \\
\hline \multicolumn{8}{|l|}{ reference: private ownership of a firm } \\
\hline public ownership of a firm & $-0.083^{* * *}$ & $-0.119^{* * *}$ & $-0.120^{* * *}$ & $-0.108^{* * *}$ & $-0.147^{* * *}$ & $-0.061^{* * *}$ & $-0.075^{* * *}$ \\
\hline tenure: less than 2 years (share) & $0.052^{* * *}$ & $0.063^{* * *}$ & $0.048^{* * *}$ & 0.001 & $0.077^{* * *}$ & $0.059^{* * *}$ & $0.020^{* * *}$ \\
\hline age: 50 years or more (share) & $-0.205^{* * *}$ & $-0.096^{* * *}$ & $-0.111^{* * *}$ & $-0.070^{* * *}$ & $-0.183^{* * *}$ & $-0.171^{* * *}$ & $-0.158^{* * *}$ \\
\hline tertiary education (share) & $0.359^{* * *}$ & $0.231^{* * *}$ & $0.155^{* * *}$ & $0.167^{* * *}$ & $0.349^{* * *}$ & $0.367^{* * *}$ & $0.402^{* * *}$ \\
\hline female (share) & $-0.026^{* * *}$ & $0.014^{* *}$ & -0.003 & $0.042^{* * *}$ & $-0.022^{* * *}$ & $-0.019^{* * *}$ & $-0.031^{* * *}$ \\
\hline constant & $0.284^{* * *}$ & $0.195^{* * *}$ & $0.323^{* * *}$ & $0.213^{* * *}$ & $0.341^{* * *}$ & $0.277^{* * *}$ & $0.226^{* * *}$ \\
\hline Observations & 135,978 & 114,892 & 26,093 & 31,079 & 271,872 & 198,862 & 153,540 \\
\hline R-squared & 0.159 & 0.132 & 0.176 & 0.190 & 0.117 & 0.166 & 0.157 \\
\hline
\end{tabular}


Table A.13: Results of RIF regression: Hungary

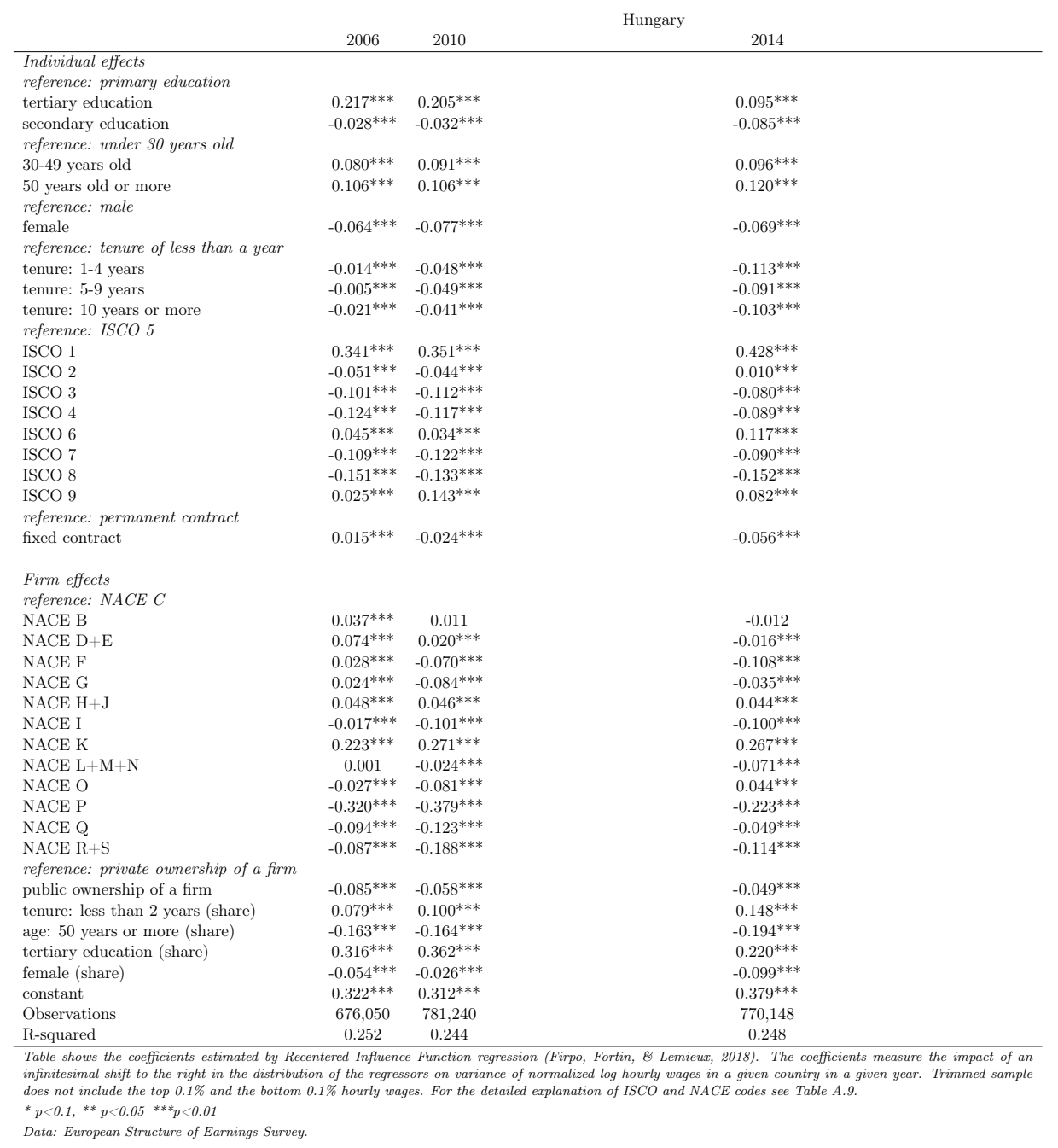


Table A.14: Blinder-Oaxaca decomposition: Bulgaria and Romania

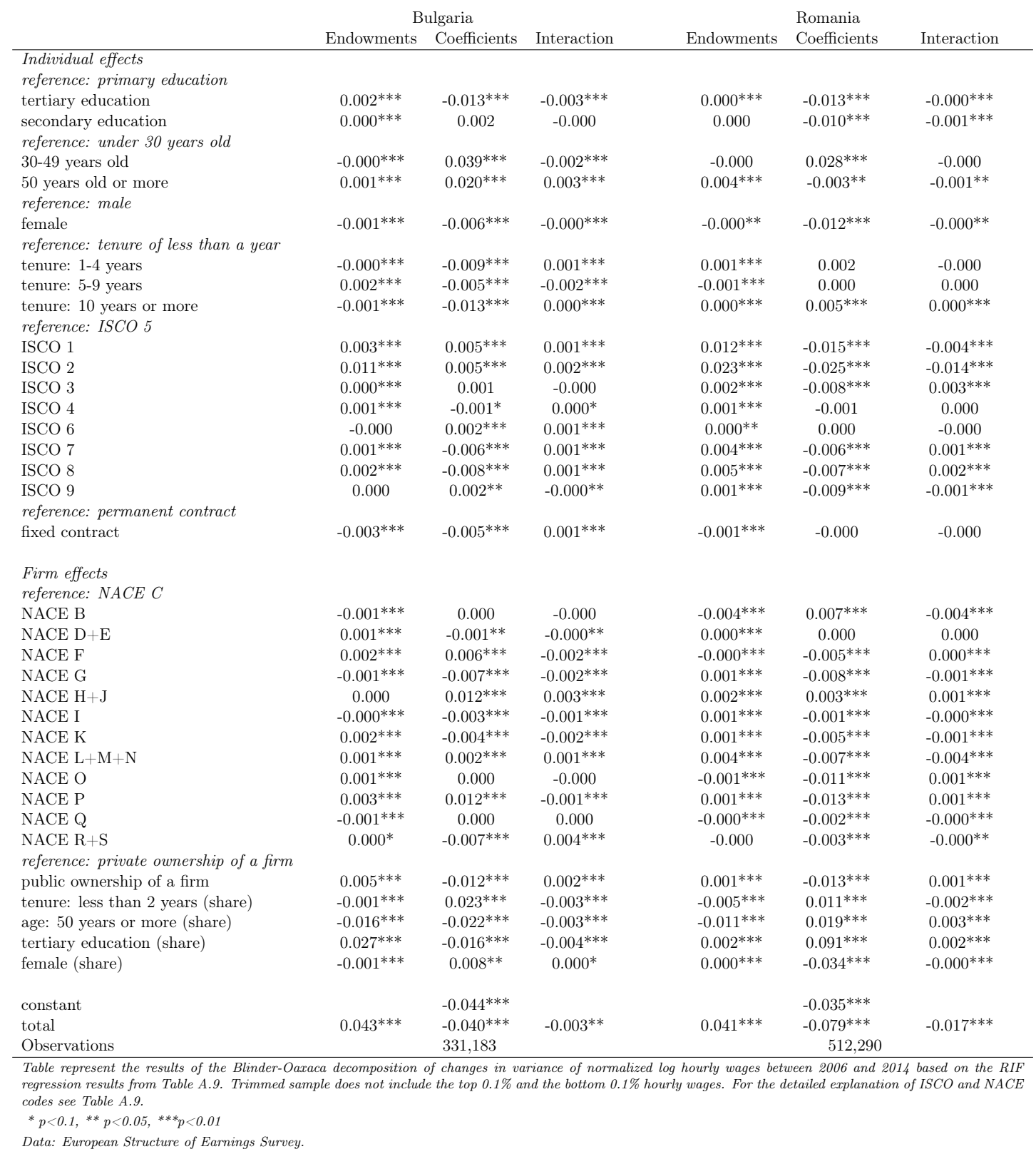


Table A.15: Blinder-Oaxaca decomposition: Czechia and Slovakia

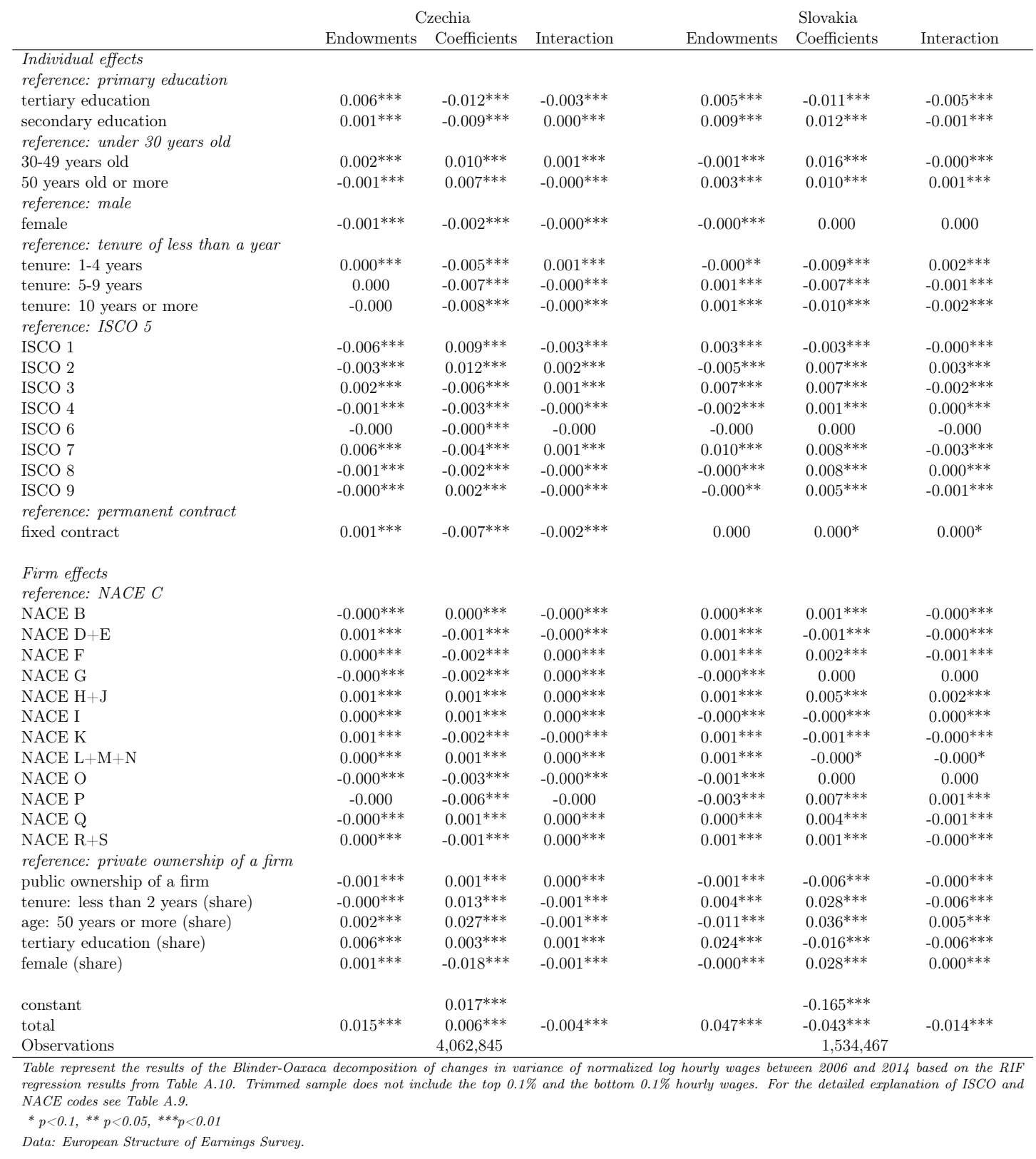


Table A.16: Blinder-Oaxaca decomposition: Estonia and Poland

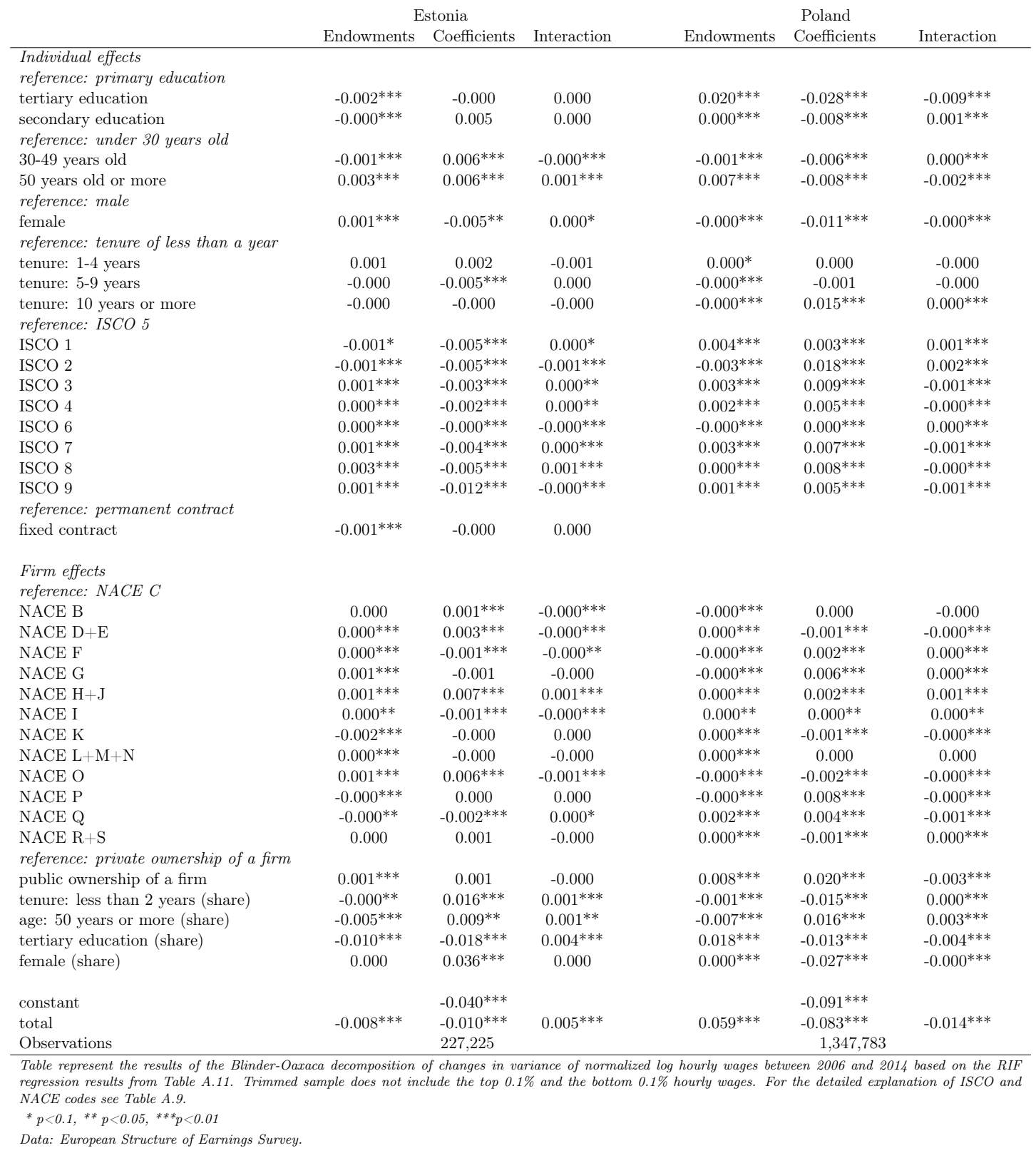


Table A.17: Blinder-Oaxaca decomposition: Lithuania and Latvia

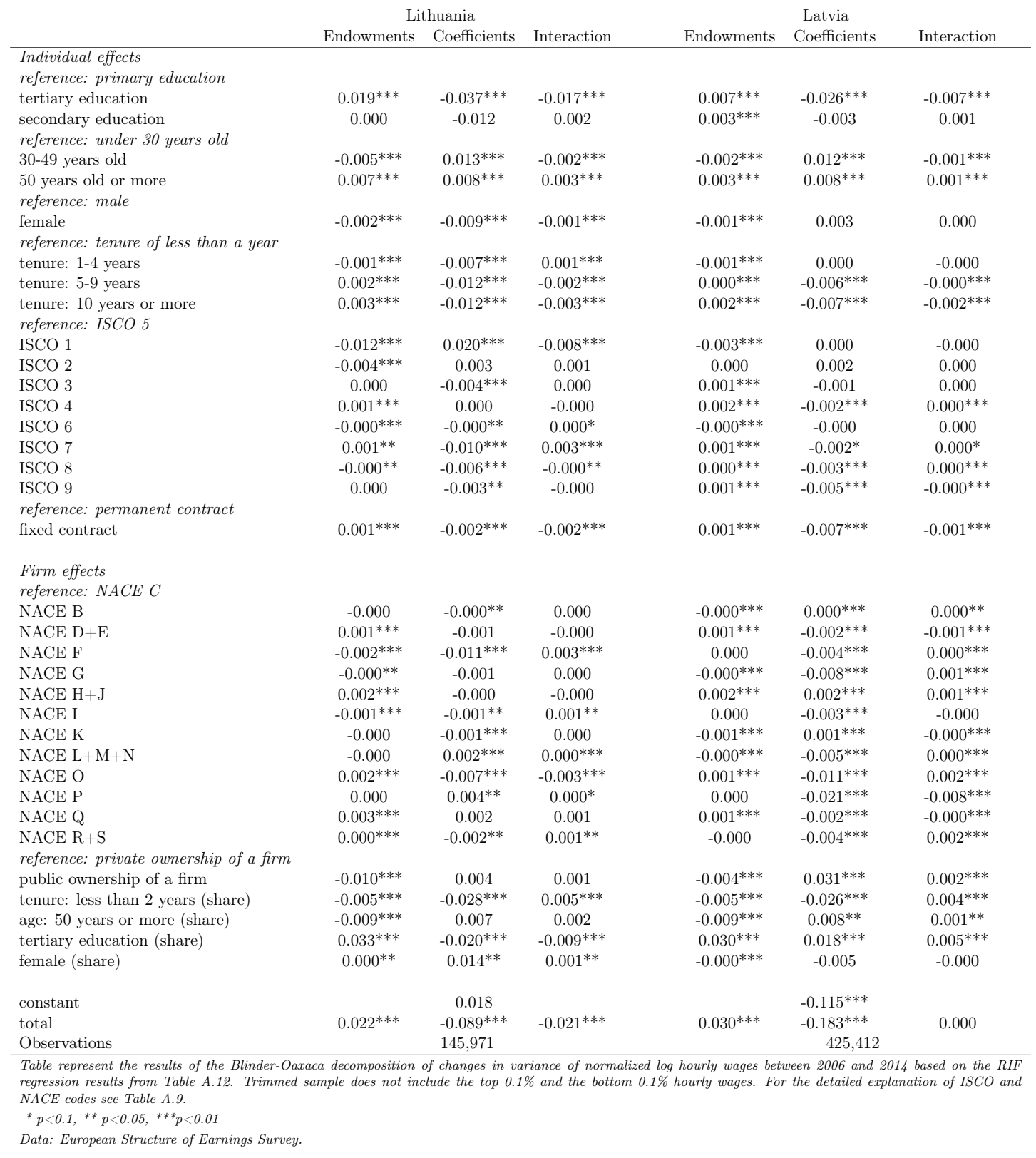


Table A.18: Blinder-Oaxaca decomposition: Hungary

\begin{tabular}{|c|c|c|c|}
\hline & Endowments & $\begin{array}{c}\text { Hungary } \\
\text { Coefficients }\end{array}$ & Interaction \\
\hline \multicolumn{4}{|l|}{ Individual effects } \\
\hline \multicolumn{4}{|l|}{ reference: primary education } \\
\hline tertiary education & $0.011^{* * *}$ & $-0.031^{* * *}$ & $-0.006^{* * *}$ \\
\hline secondary education & $0.001 * * *$ & $-0.033^{* * *}$ & $0.001^{* * *}$ \\
\hline \multicolumn{4}{|l|}{ reference: under 30 years old } \\
\hline $30-49$ years old & $0.002^{* * *}$ & $0.009^{* * *}$ & $0.001^{* * *}$ \\
\hline 50 years old or more & $-0.001^{* * *}$ & $0.004^{* * *}$ & $-0.000^{* * *}$ \\
\hline \multicolumn{4}{|l|}{ reference: male } \\
\hline female & $0.002^{* * *}$ & $-0.003^{* * *}$ & $0.000^{* * *}$ \\
\hline \multicolumn{4}{|l|}{ reference: tenure of less than a year } \\
\hline tenure: $1-4$ years & -0.000 & $-0.032^{* * *}$ & -0.000 \\
\hline tenure: $5-9$ years & $0.000^{* * *}$ & $-0.018^{* * *}$ & $0.002^{* * *}$ \\
\hline \multicolumn{3}{|l|}{ reference: $I S C O 5$} & $0.003^{* * *}$ \\
\hline ISCO 1 & $-0.005^{* * *}$ & $0.007^{* * *}$ & $-0.001 * * *$ \\
\hline ISCO 2 & $-0.001 * * *$ & $0.010^{* * *}$ & $0.002^{* * *}$ \\
\hline ISCO 3 & $-0.001^{* * *}$ & $0.004^{* * *}$ & $0.000^{* * *}$ \\
\hline ISCO 4 & $0.004^{* * *}$ & $0.003^{* * *}$ & $-0.001 * * *$ \\
\hline ISCO 6 & -0.000 & $0.000^{* * *}$ & -0.000 \\
\hline ISCO 7 & $-0.001 * * *$ & $0.003^{* * *}$ & $0.000^{* * *}$ \\
\hline ISCO 8 & $-0.002^{* * *}$ & -0.000 & -0.000 \\
\hline ISCO 9 & $0.001^{* * *}$ & $0.006^{* * *}$ & $0.003^{* * *}$ \\
\hline \multicolumn{4}{|l|}{ reference: permanent contract } \\
\hline \multicolumn{4}{|l|}{ Firm effects } \\
\hline NACE B & $0.000^{* * *}$ & $-0.000^{* * *}$ & $-0.000^{* * *}$ \\
\hline $\mathrm{NACE} D+\mathrm{E}$ & $-0.000^{* * *}$ & $-0.003 * * *$ & $0.000^{* * *}$ \\
\hline NACE F & $-0.000^{* * *}$ & $-0.006^{* * *}$ & $0.001^{* * *}$ \\
\hline NACE G & 0.000 & $-0.006^{* * *}$ & -0.000 \\
\hline $\mathrm{NACE} \mathrm{H}+\mathrm{J}$ & $0.001^{* * *}$ & -0.000 & -0.000 \\
\hline NACE I & $0.000^{* *}$ & $-0.002^{* * *}$ & $0.000^{* * *}$ \\
\hline NACE K & $0.002^{* * *}$ & $0.001^{* * *}$ & $0.000^{* * *}$ \\
\hline $\mathrm{NACE} \mathrm{L}+\mathrm{M}+\mathrm{N}$ & 0.000 & $-0.004^{* * *}$ & $-0.001 * * *$ \\
\hline NACE O & $-0.000^{* * *}$ & $0.010^{* * *}$ & $0.001^{* * *}$ \\
\hline NACE P & $0.006^{* * *}$ & $0.014^{* * *}$ & $-0.002 * * *$ \\
\hline NACE Q & $0.000^{* * *}$ & $0.004^{* * *}$ & $-0.000^{* * *}$ \\
\hline $\mathrm{NACE} \mathrm{R}+\mathrm{S}$ & $0.002^{* * *}$ & $-0.001 * * *$ & $0.001^{* * *}$ \\
\hline \multicolumn{4}{|l|}{ reference: private ownership of a firm } \\
\hline public ownership of a firm & $0.003^{* * *}$ & $0.017^{* * *}$ & $-0.001 * * *$ \\
\hline tenure: less than 2 years (share) & $0.006^{* * *}$ & $0.024^{* * *}$ & $0.005^{* * *}$ \\
\hline age: 50 years or more (share) & $0.001^{* * *}$ & $-0.010^{* * *}$ & $0.000^{* * *}$ \\
\hline tertiary education (share) & $0.015^{* * *}$ & $-0.026^{* * *}$ & $-0.005^{* * *}$ \\
\hline female (share) & $0.001^{* * *}$ & $-0.024^{* * *}$ & $0.001^{* * *}$ \\
\hline \multicolumn{2}{|l|}{ constant } & $0.057^{* * *}$ & \\
\hline total & $0.046^{* * *}$ & $-0.055^{* * *}$ & $0.005^{* * *}$ \\
\hline Observations & & $1,446,198$ & \\
\hline \multirow{2}{*}{\multicolumn{4}{|c|}{$\begin{array}{l}\text { Table represent the results of the Blinder-Oaxaca decomposition of changes in variance of normalized log hourly } \\
\text { wages between } 2006 \text { and } 2014 \text { based on the RIF regression results from Table A.13. Trimmed sample does not } \\
\text { include the top } 0.1 \% \text { and the bottom } 0.1 \% \text { hourly wages. For the detailed explanation of ISCO and NACE } \\
\text { codes see Table A.9. } \\
{ }^{*} p<0.1,{ }^{* *} p<0.05,{ }^{* * *} p<0.01\end{array}$}} \\
\hline & & & \\
\hline
\end{tabular}


Table A.19: Results of RIF regression: Bulgaria and Romania (excluding public sector)

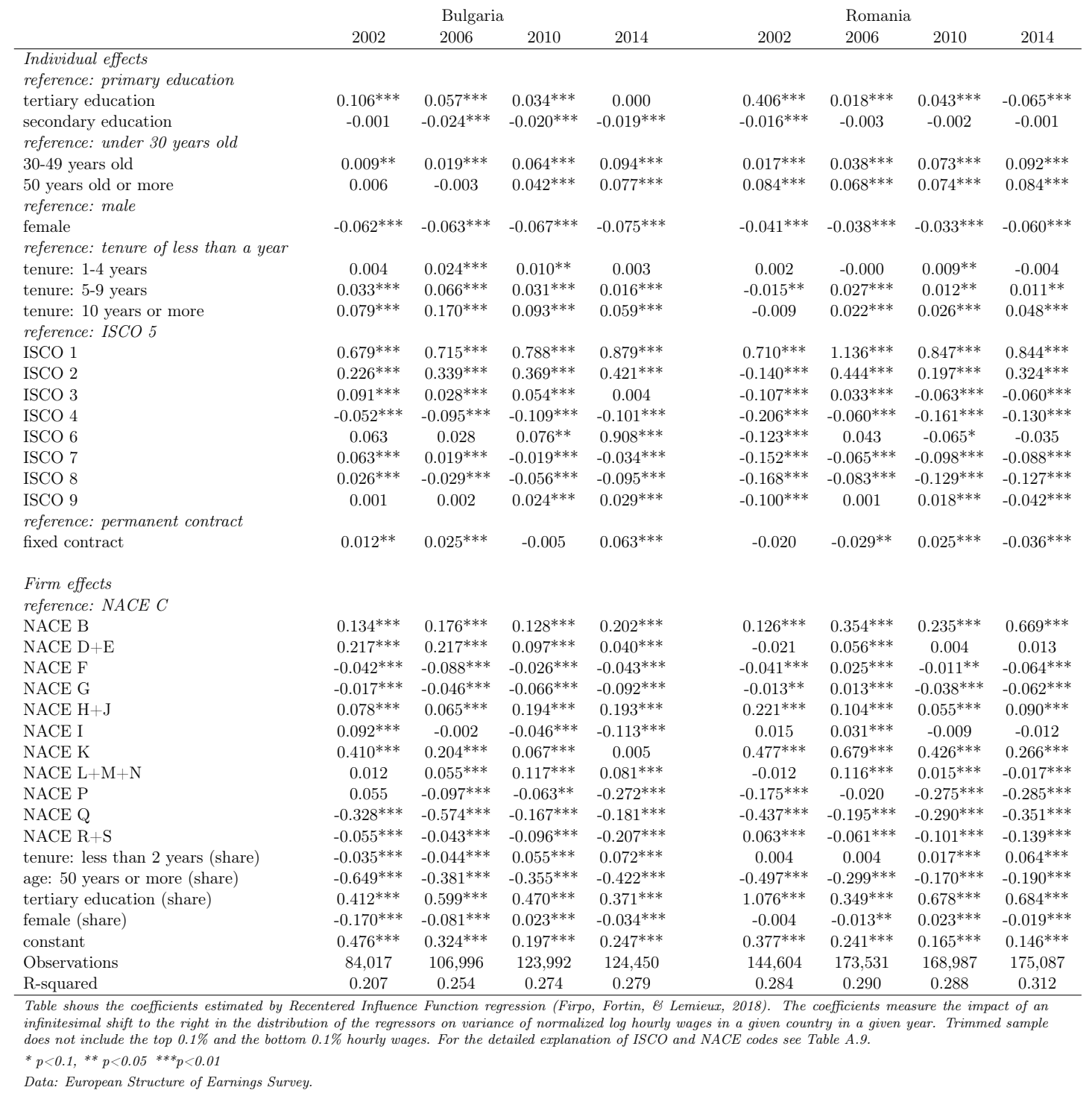


Table A.20: Results of RIF regression: Czechia and Slovakia (excluding public sector)

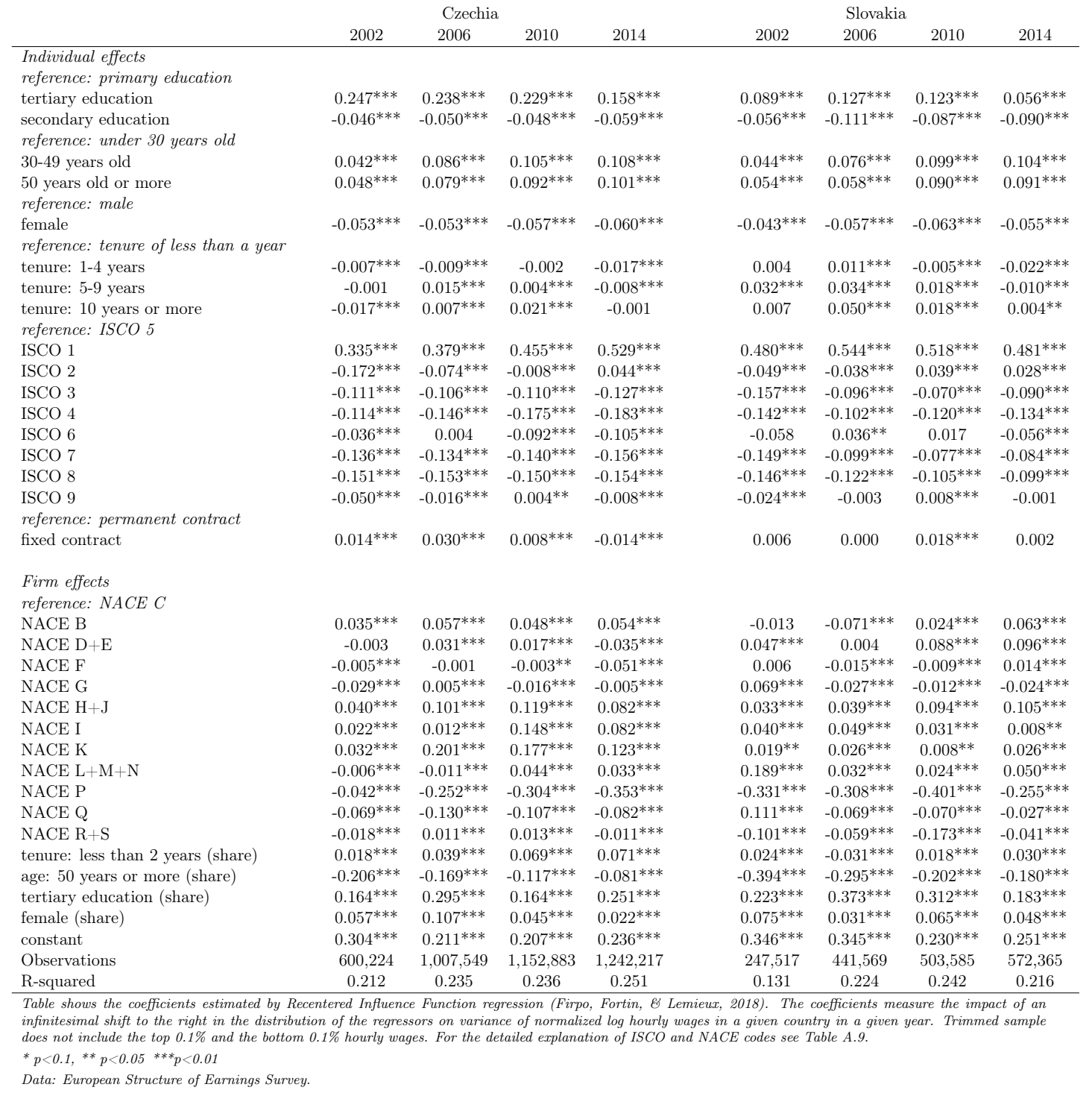


Table A.21: Results of RIF regression: Estonia and Poland (excluding public sector)

\begin{tabular}{|c|c|c|c|c|c|c|c|}
\hline & \multicolumn{3}{|c|}{ Estonia } & \multicolumn{4}{|c|}{ Poland } \\
\hline & 2006 & 2010 & 2014 & 2002 & 2006 & 2010 & 2014 \\
\hline \multicolumn{8}{|l|}{ Individual effects } \\
\hline \multicolumn{8}{|l|}{ reference: primary education } \\
\hline tertiary education & $0.129^{* * *}$ & $0.084^{* * *}$ & $0.112^{* * *}$ & $0.301^{* * *}$ & $0.267 * * *$ & $0.172^{* * *}$ & $0.126^{* * *}$ \\
\hline secondary education & $-0.017^{* * *}$ & $-0.030^{* * *}$ & $-0.013^{* * *}$ & $-0.012^{* * *}$ & -0.005 & $-0.016^{* * *}$ & $-0.020 * * *$ \\
\hline \multicolumn{8}{|l|}{ reference: under 30 years old } \\
\hline $30-49$ years old & $0.077^{* * *}$ & $0.091^{* * *}$ & $0.091^{* * *}$ & $0.098^{* * *}$ & $0.129^{* * *}$ & $0.131^{* * *}$ & $0.132^{* * *}$ \\
\hline \multicolumn{8}{|l|}{ reference: male } \\
\hline female & $-0.054^{* * *}$ & $-0.061^{* * *}$ & $-0.081^{* * *}$ & $-0.056^{* * *}$ & $-0.077^{* * *}$ & $-0.084^{* * *}$ & $-0.092 * * *$ \\
\hline \multicolumn{8}{|l|}{ reference: tenure of less than a year } \\
\hline tenure: $1-4$ years & $-0.026^{* * *}$ & $-0.014 * * *$ & -0.006 & $-0.028^{* * *}$ & $-0.008^{* *}$ & $-0.008^{* * *}$ & 0.003 \\
\hline tenure: $5-9$ years & 0.006 & $-0.013^{* *}$ & 0.005 & $-0.012^{* * *}$ & 0.003 & 0.000 & -0.001 \\
\hline $\begin{array}{l}\text { tenure: } 10 \text { years or more } \\
\text { reference: ISCO } 5\end{array}$ & \multicolumn{6}{|c|}{ reference: $I S C O 5$} & $0.035^{* * *}$ \\
\hline ISCO 1 & $0.461^{* * *}$ & $0.518^{* * *}$ & $0.369^{* * *}$ & $0.681^{* * *}$ & $0.521^{* * *}$ & $0.509^{* * *}$ & $0.482^{* * *}$ \\
\hline ISCO 2 & $0.184^{* * *}$ & $0.132^{* * *}$ & $0.134^{* * *}$ & $0.042^{* * *}$ & $-0.075^{* * *}$ & $-0.026^{* * *}$ & $-0.052^{* * *}$ \\
\hline ISCO 3 & 0.009 & $-0.071^{* * *}$ & $-0.025^{* * *}$ & $-0.083^{* * *}$ & $-0.164 * * *$ & $-0.120 * * *$ & $-0.133^{* * *}$ \\
\hline $\mathrm{ISCO} 4$ & $-0.133^{* * *}$ & $-0.156^{* * *}$ & $-0.135^{* * *}$ & $-0.170^{* * *}$ & $-0.204^{* * *}$ & $-0.178^{* * *}$ & $-0.183^{* * *}$ \\
\hline ISCO 6 & 0.175 & $0.129^{* *}$ & $-0.097^{*}$ & $-0.122^{* * *}$ & $-0.208^{* * *}$ & 0.033 & $-0.073^{* * *}$ \\
\hline ISCO 7 & $-0.017 * * *$ & $-0.063^{* * *}$ & $-0.028^{* * *}$ & $-0.068^{* * *}$ & $-0.118^{* * *}$ & $-0.080^{* * *}$ & $-0.091^{* * *}$ \\
\hline ISCO 8 & $-0.047 * * *$ & $-0.075^{* * *}$ & $-0.073^{* * *}$ & $-0.126^{* * *}$ & $-0.178^{* * *}$ & $-0.124^{* * *}$ & $-0.140 * * *$ \\
\hline ISCO 9 & $0.124^{* * *}$ & $0.061^{* * *}$ & $0.051^{* * *}$ & $-0.031^{* * *}$ & $-0.057^{* * *}$ & $-0.011^{* * *}$ & $-0.010^{* * *}$ \\
\hline \multicolumn{8}{|l|}{ reference: permanent contract } \\
\hline fixed contract & $0.048^{* * *}$ & $0.070^{* * *}$ & $0.083^{* * *}$ & & & & \\
\hline \multicolumn{8}{|l|}{$\begin{array}{l}\text { Firm effects } \\
\text { reference: } N A C E C\end{array}$} \\
\hline NACE B & 0.011 & $0.103^{* * *}$ & $0.094^{* * *}$ & $0.257^{* * *}$ & $0.423^{* * *}$ & $0.178^{* * *}$ & $0.278^{* * *}$ \\
\hline $\mathrm{NACE} D+\mathrm{E}$ & $-0.081^{* * *}$ & $-0.034^{* *}$ & $-0.031^{* *}$ & $0.070^{* * *}$ & $0.040^{* * *}$ & $0.018^{* * *}$ & $0.071^{* * *}$ \\
\hline NACE F & $0.034^{* * *}$ & $0.017^{* * *}$ & 0.006 & $-0.030^{* * *}$ & $-0.038^{* * *}$ & $-0.016^{* * *}$ & $-0.017^{* * *}$ \\
\hline NACE G & $0.055^{* * *}$ & $0.018^{* * *}$ & $0.048^{* * *}$ & $-0.043^{* * *}$ & $-0.060^{* * *}$ & $-0.035^{* * *}$ & $-0.006^{* *}$ \\
\hline $\mathrm{NACE} \mathrm{H}+\mathrm{J}$ & $0.038^{* * *}$ & $0.106^{* * *}$ & $0.110^{* * *}$ & $0.087^{* * *}$ & $0.049^{* * *}$ & $0.052^{* * *}$ & $0.054^{* * *}$ \\
\hline NACE I & $0.065^{* * *}$ & $0.031^{* * *}$ & $0.028^{* * *}$ & $0.026^{* * *}$ & -0.008 & $-0.019^{* * *}$ & $-0.016^{* * *}$ \\
\hline NACE K & $0.172^{* * *}$ & $0.159^{* * *}$ & $0.187^{* * *}$ & $-0.122^{* * *}$ & $0.062^{* * *}$ & $0.020^{* * *}$ & $-0.013^{* * *}$ \\
\hline $\mathrm{NACE} \mathrm{L}+\mathrm{M}+\mathrm{N}$ & $0.113^{* * *}$ & $0.037^{* * *}$ & $0.085^{* * *}$ & 0.006 & $0.017^{* * *}$ & $0.032^{* * *}$ & $0.024^{* * *}$ \\
\hline NACE P & $-0.218^{* * *}$ & $-0.248^{* * *}$ & $-0.081^{* * *}$ & $-0.096^{* * *}$ & $-0.393^{* * *}$ & $-0.336^{* * *}$ & $-0.261^{* * *}$ \\
\hline NACE Q & 0.012 & 0.013 & $0.033^{* * *}$ & $-0.260^{* * *}$ & $-0.205^{* * *}$ & $-0.126^{* * *}$ & $-0.108^{* * *}$ \\
\hline $\mathrm{NACE} R+\mathrm{S}$ & -0.001 & 0.016 & 0.013 & $-0.031^{* * *}$ & 0.013 & $0.040^{* * *}$ & $0.044^{* * *}$ \\
\hline tenure: less than 2 years (share) & $-0.044^{* * *}$ & $0.053^{* * *}$ & $0.022^{* * *}$ & $0.078^{* * *}$ & $0.050^{* * *}$ & $0.039^{* * *}$ & $0.038^{* * *}$ \\
\hline age: 50 years or more (share) & $-0.116^{* * *}$ & $-0.106^{* * *}$ & $-0.058^{* * *}$ & $-0.297^{* * *}$ & $-0.166^{* * *}$ & $-0.151^{* * *}$ & $-0.089^{* * *}$ \\
\hline tertiary education (share) & $0.089^{* * *}$ & $0.149^{* * *}$ & $0.070^{* * *}$ & $0.758^{* * *}$ & $0.511^{* * *}$ & $0.434^{* * *}$ & $0.367^{* * *}$ \\
\hline female (share) & $-0.032^{* * *}$ & $0.051^{* * *}$ & $0.054^{* * *}$ & $0.105^{* * *}$ & $0.040^{* * *}$ & $0.032^{* * *}$ & 0.000 \\
\hline constant & $0.249^{* * *}$ & $0.193^{* * *}$ & $0.162^{* * *}$ & $0.195^{* * *}$ & $0.227 * * *$ & $0.139^{* * *}$ & $0.138^{* * *}$ \\
\hline Observations & 76,863 & 66,752 & 69,999 & 293,325 & 316,821 & 336,871 & 404,022 \\
\hline R-squared & 0.190 & 0.225 & 0.165 & 0.269 & 0.245 & 0.252 & 0.227 \\
\hline
\end{tabular}


Table A.22: Results of RIF regression: Lithuania and Latvia (excluding public sector)

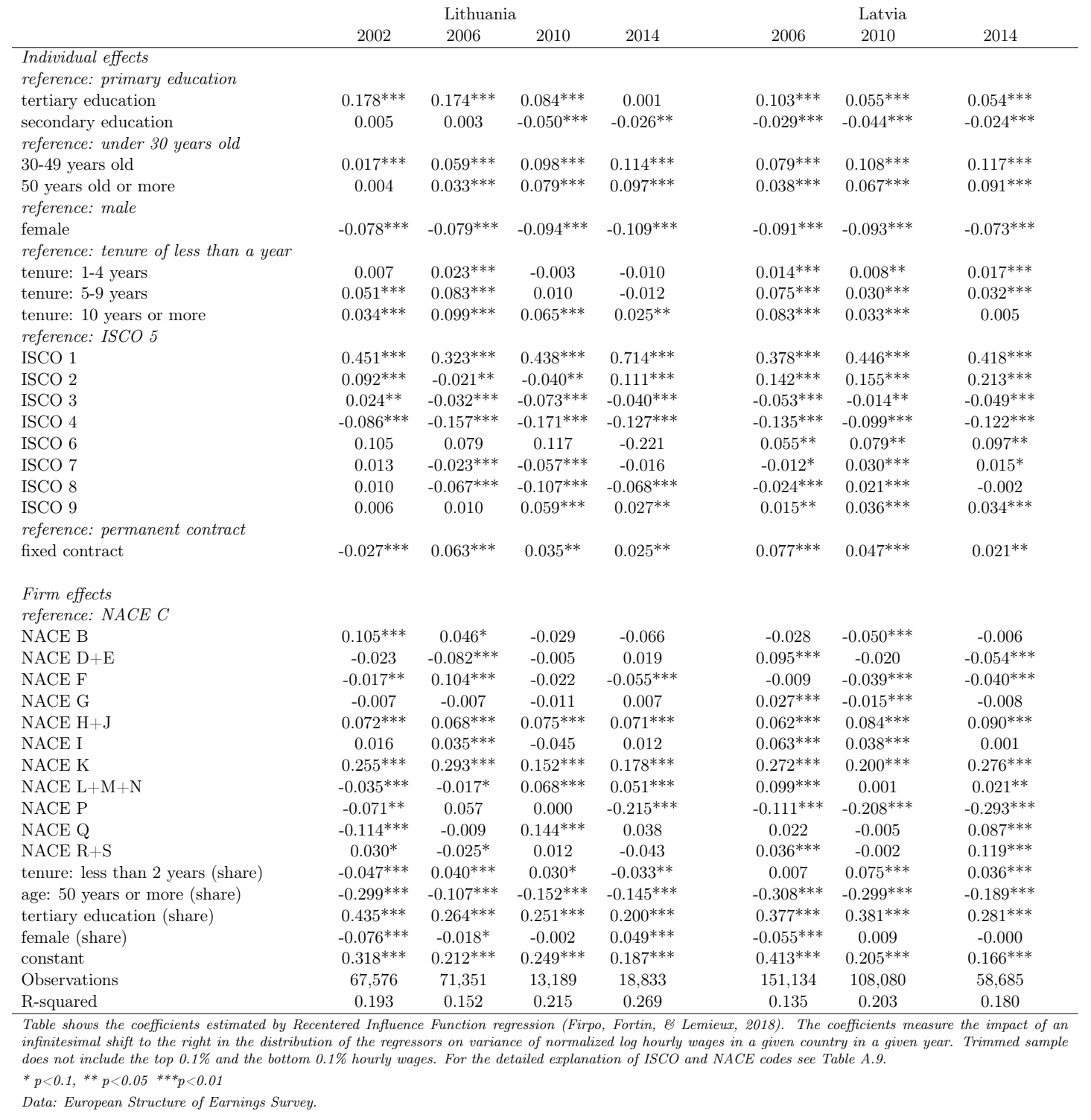


Table A.23: Results of RIF regression: Hungary (excluding public sector)

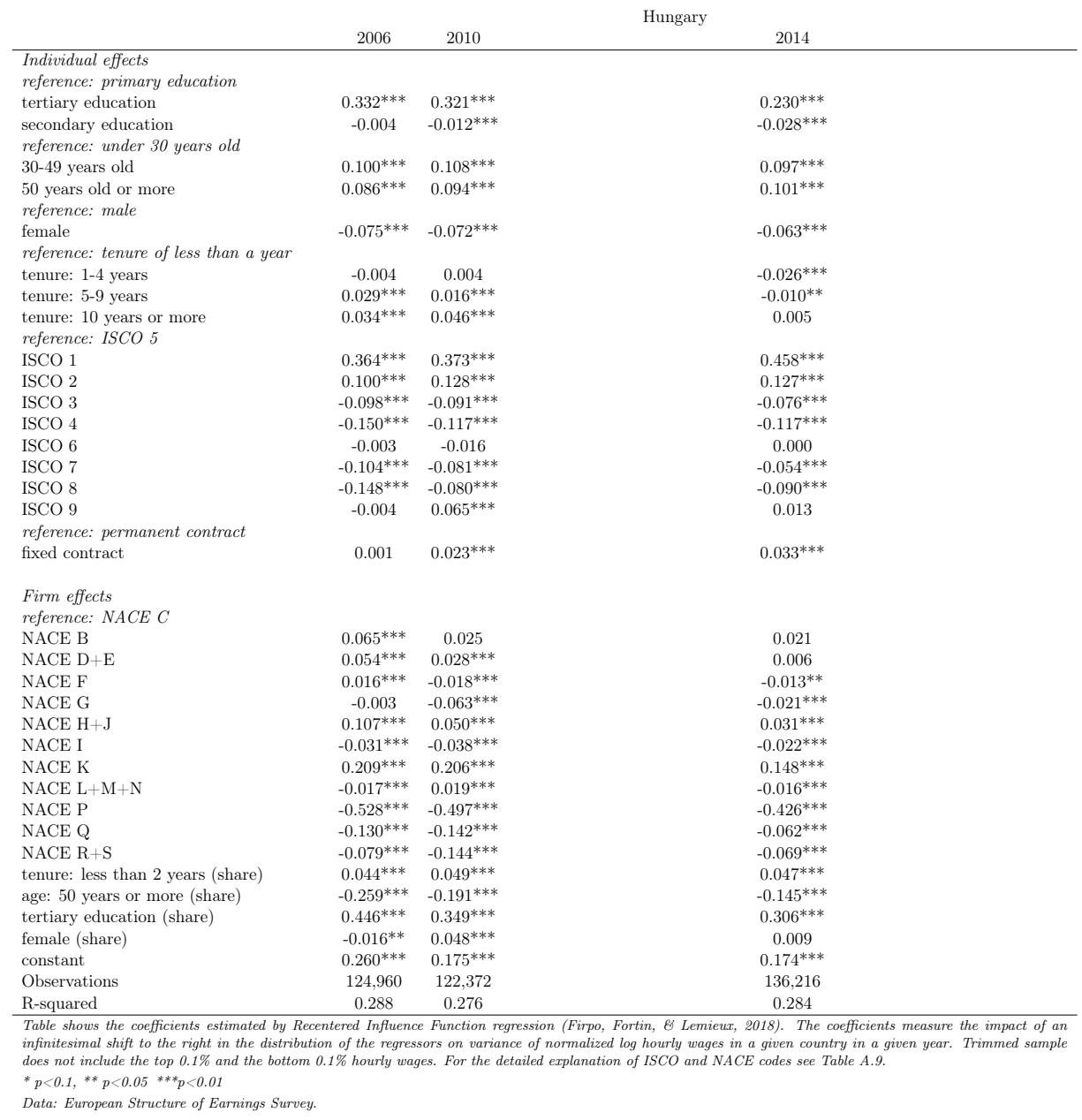


Table A.24: Blinder-Oaxaca decomposition: Bulgaria and Romania (excluding public sector)

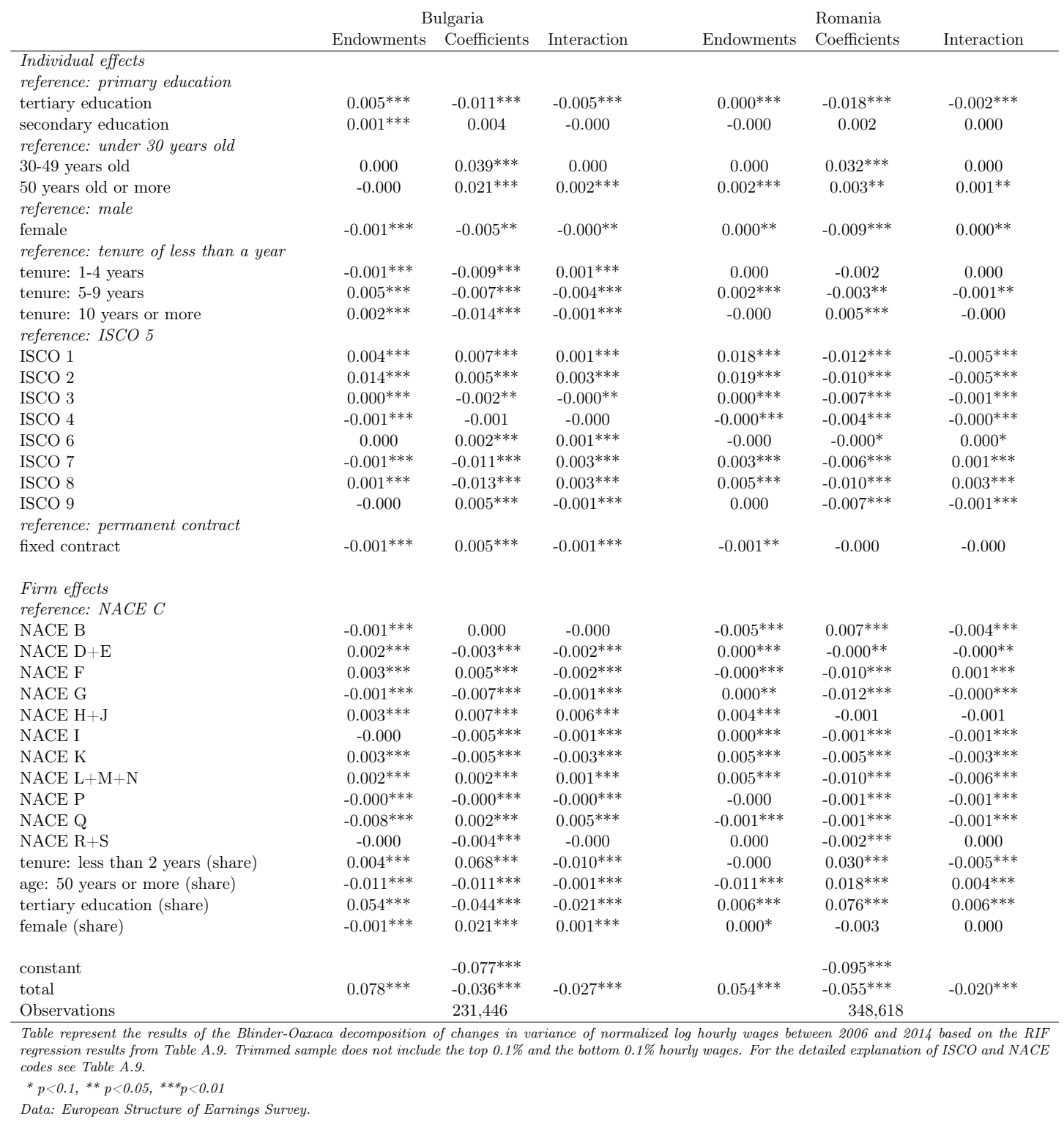


Table A.25: Blinder-Oaxaca decomposition: Czechia and Slovakia (excluding public sector)

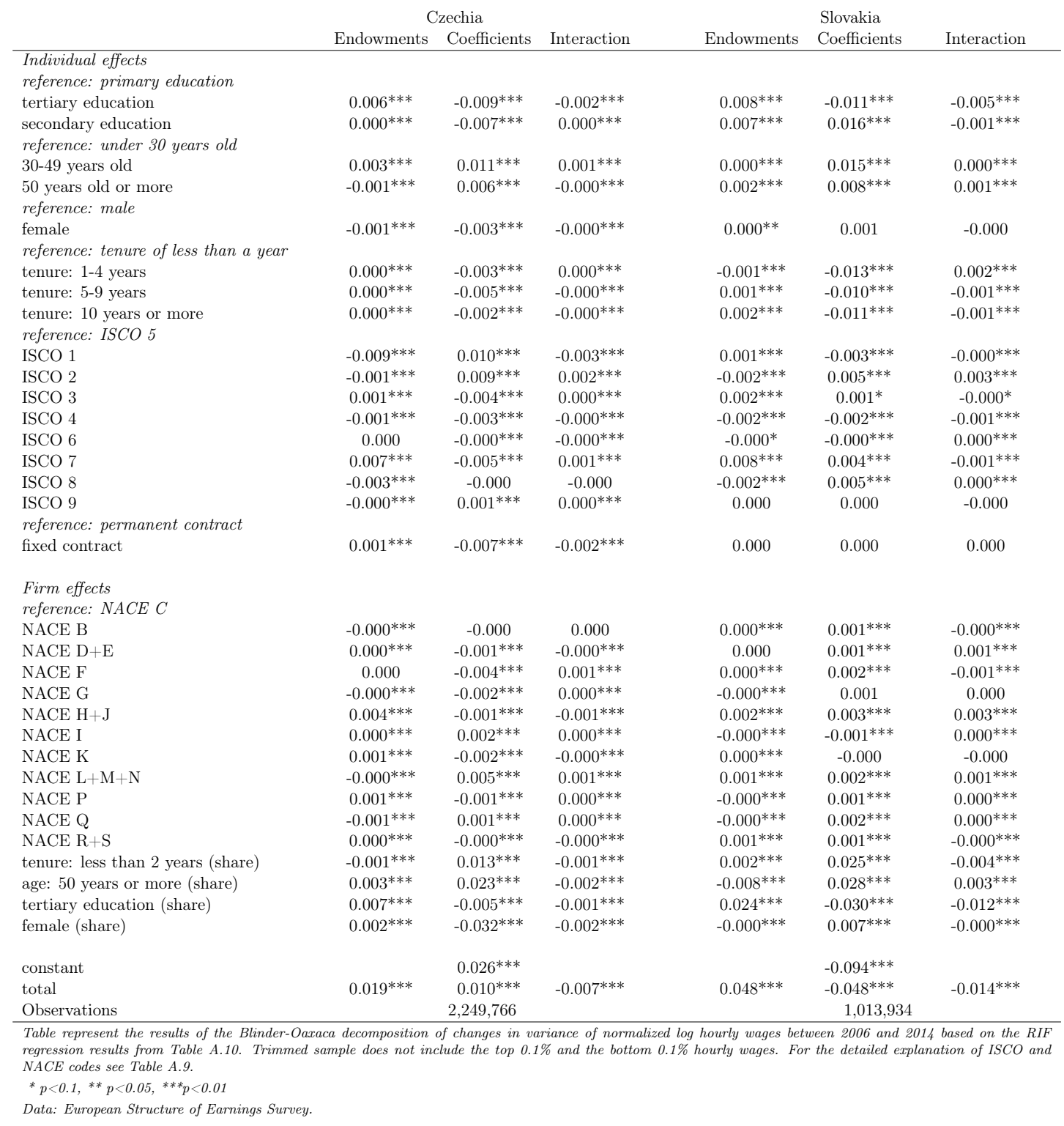


Table A.26: Blinder-Oaxaca decomposition: Estonia and Poland (excluding public sector)

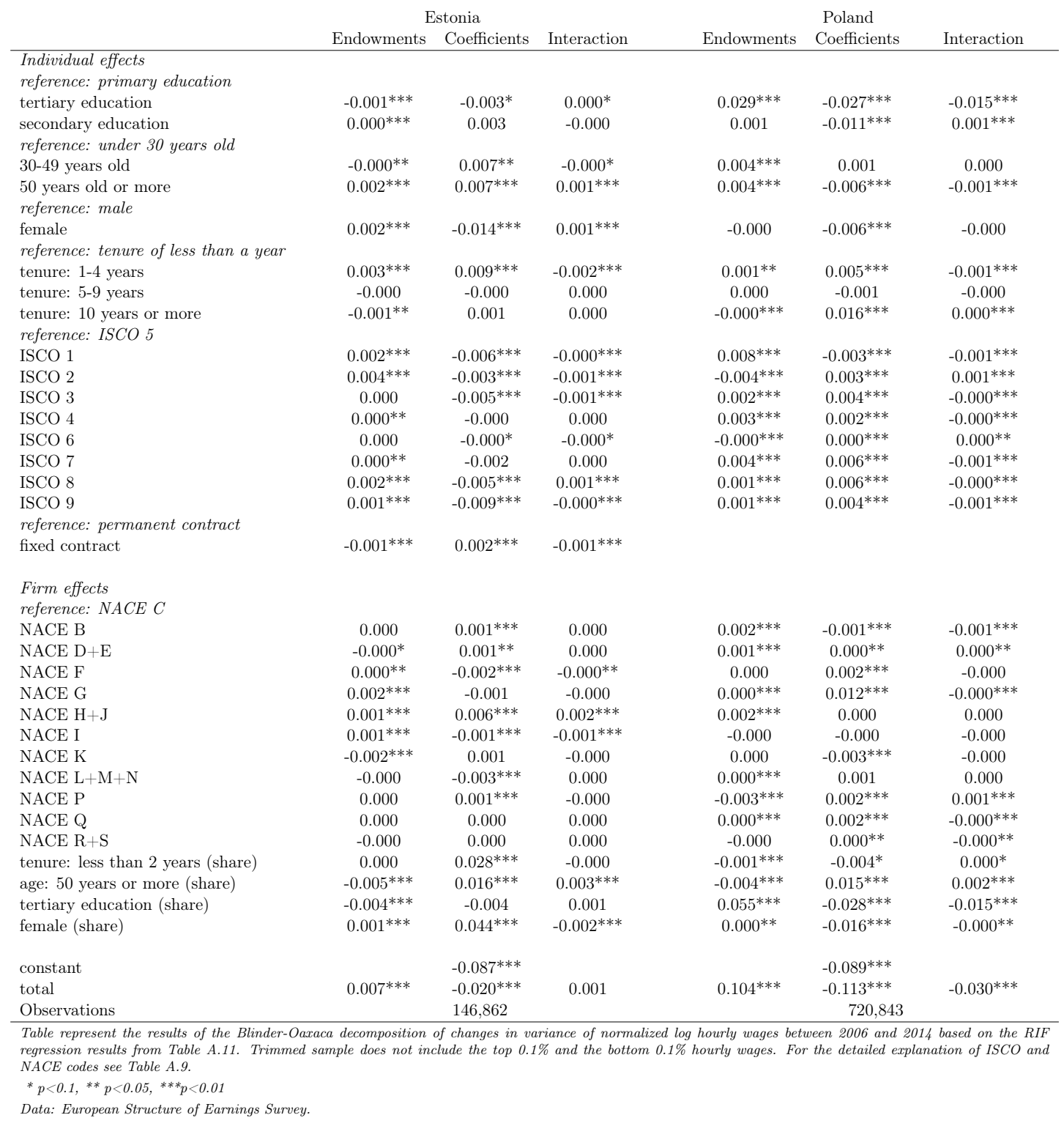


Table A.27: Blinder-Oaxaca decomposition: Lithuania and Latvia (excluding public sector)

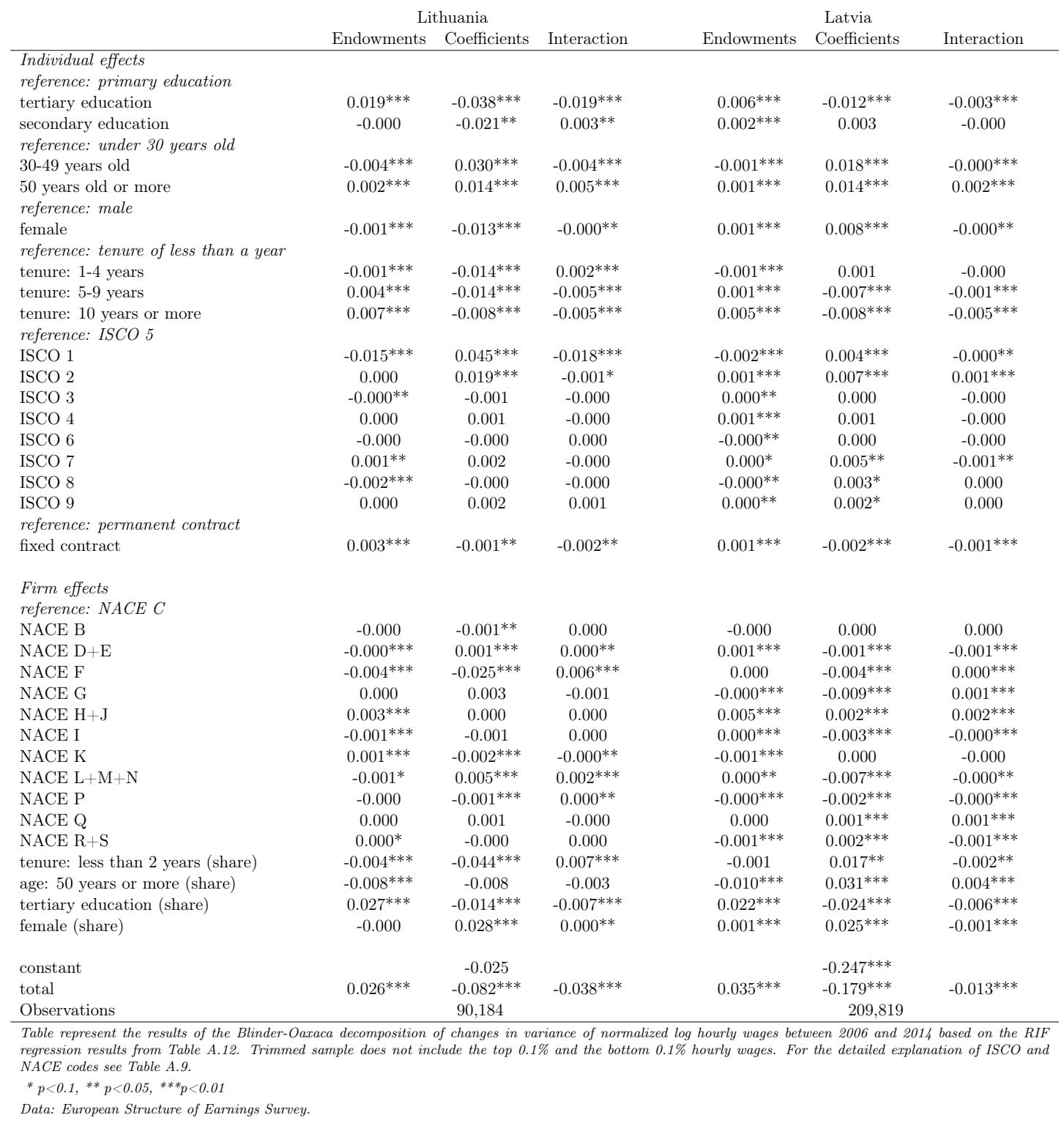


Table A.28: Blinder-Oaxaca decomposition: Hungary (excluding public sector)

\begin{tabular}{|c|c|c|c|}
\hline & Endowments & $\begin{array}{c}\text { Hungary } \\
\text { Coefficients }\end{array}$ & Interaction \\
\hline \multicolumn{4}{|l|}{ Individual effects } \\
\hline \multicolumn{4}{|l|}{ reference: primary education } \\
\hline tertiary education & $0.018^{* * *}$ & $-0.017 * * *$ & $-0.005^{* * *}$ \\
\hline secondary education & 0.000 & $-0.016^{* * *}$ & $0.001^{* * *}$ \\
\hline \multicolumn{4}{|l|}{ reference: under 30 years old } \\
\hline $30-49$ years old & $0.004^{* * *}$ & -0.001 & -0.000 \\
\hline \multicolumn{3}{|l|}{ reference: male } & $-0.000^{* *}$ \\
\hline female & $0.002^{* * *}$ & $0.005^{* * *}$ & $-0.000^{* * *}$ \\
\hline \multicolumn{4}{|l|}{ reference: tenure of less than a year } \\
\hline tenure: $1-4$ years & 0.000 & $-0.009^{* * *}$ & $0.000^{*}$ \\
\hline tenure: $5-9$ years & $0.000^{* * *}$ & $-0.008^{* * *}$ & $-0.000 * * *$ \\
\hline $\begin{array}{l}\text { tenure: } 10 \text { years or more } \\
\text { reference: ISCO } 5\end{array}$ & \\
\hline ISCO 1 & $-0.007^{* * *}$ & $0.008^{* * *}$ & $-0.002 * * *$ \\
\hline ISCO 2 & $0.003^{* * *}$ & $0.002 *$ & $0.001 *$ \\
\hline ISCO 3 & $-0.001 * * *$ & $0.003^{*}$ & $0.000^{*}$ \\
\hline ISCO 4 & $0.003^{* * *}$ & $0.003^{* * *}$ & $-0.001^{* * *}$ \\
\hline ISCO 6 & 0.000 & 0.000 & -0.000 \\
\hline ISCO 7 & $-0.001^{* * *}$ & $0.011^{* * *}$ & $0.000^{* * *}$ \\
\hline ISCO 8 & $-0.004^{* * *}$ & $0.011^{* * *}$ & $0.002^{* * *}$ \\
\hline ISCO 9 & -0.000 & 0.002 & 0.001 \\
\hline \multicolumn{4}{|l|}{ reference: permanent contract } \\
\hline \multicolumn{4}{|l|}{ Firm effects } \\
\hline NACE B & $0.000^{*}$ & $-0.000^{*}$ & -0.000 \\
\hline NACE D + E & $-0.000^{* * *}$ & $-0.001^{* * *}$ & $0.000^{* * *}$ \\
\hline NACE F & $-0.000 * * *$ & $-0.002 * * *$ & $0.001^{* * *}$ \\
\hline NACE G & 0.000 & $-0.003^{* * *}$ & $0.000^{* * *}$ \\
\hline $\mathrm{NACE} \mathrm{H}+\mathrm{J}$ & $0.004^{* * *}$ & $-0.004^{* * *}$ & $-0.003^{* * *}$ \\
\hline NACE I & -0.000 & 0.000 & 0.000 \\
\hline NACE $\mathrm{K}$ & $0.003^{* * *}$ & $-0.002^{* * *}$ & $-0.001 * * *$ \\
\hline $\mathrm{NACE} \mathrm{L}+\mathrm{M}+\mathrm{N}$ & $-0.000^{* * *}$ & 0.000 & 0.000 \\
\hline NACE P & $0.004^{* * *}$ & $0.003^{* * *}$ & $-0.001 * * *$ \\
\hline NACE Q & $0.000^{* * *}$ & $0.001^{* * *}$ & $-0.000 * * *$ \\
\hline NACE $R+S$ & $0.001^{* * *}$ & 0.000 & -0.000 \\
\hline tenure: less than 2 years (share) & $-0.000^{* * *}$ & 0.002 & -0.000 \\
\hline age: 50 years or more (share) & $0.001^{* * *}$ & $0.028^{* * *}$ & $-0.001 * * *$ \\
\hline tertiary education (share) & $0.026^{* * *}$ & $-0.026^{* * *}$ & $-0.008^{* * *}$ \\
\hline female (share) & $0.000^{* *}$ & $0.011^{* * *}$ & $-0.001^{* * *}$ \\
\hline constant & & $-0.086^{* * *}$ & \\
\hline total & $0.055^{* * *}$ & $-0.087^{* * *}$ & $-0.018^{* * *}$ \\
\hline Observations & & 261,176 & \\
\hline \multirow{2}{*}{\multicolumn{4}{|c|}{$\begin{array}{l}\text { Table represent the results of the Blinder-Oaxaca decomposition of changes in variance of normalized log hourly } \\
\text { wages between } 2006 \text { and } 2014 \text { based on the RIF regression results from Table A.13. Trimmed sample does not } \\
\text { include the top } 0.1 \% \text { and the bottom } 0.1 \% \text { hourly wages. For the detailed explanation of ISCO and NACE } \\
\text { codes see Table A.9. } \\
{ }^{*} p<0.1,{ }^{* *} p<0.05,{ }^{* * *} p<0.01\end{array}$}} \\
\hline & & & \\
\hline Data: European Structure of Earr & & & \\
\hline
\end{tabular}

